\title{
Effects Of Clam Aquaculture On Nektonic And Benthic Assemblages In Two Shallow-Water Estuaries
}

\author{
Mark Luckenbach \\ Virginia Institute of Marine Science \\ JN Kraeuter \\ D Bushek
}

Follow this and additional works at: https://scholarworks.wm.edu/vimsarticles

Part of the Marine Biology Commons

\section{Recommended Citation}

Luckenbach, Mark; Kraeuter, JN; and Bushek, D, Effects Of Clam Aquaculture On Nektonic And Benthic Assemblages In Two Shallow-Water Estuaries (2016). Journal Of Shellfish Research, 35(4), 757-775. 10.2983/035.035.0405 


\title{
EFFECTS OF CLAM AQUACULTURE ON NEKTONIC AND BENTHIC ASSEMBLAGES IN TWO SHALLOW-WATER ESTUARIES
}

\author{
MARK W. LUCKENBACH, ${ }^{1 *}$ JOHN N. KRAEUTER ${ }^{2,3}$ AND DAVID BUSHEK ${ }^{2}$ \\ ${ }^{1}$ Virginia Institute of Marine Science, College of William Mary, 1208 Greate Rd., Gloucester Point, VA \\ 23062; ${ }^{2}$ Haskin Shellfish Research Laboratory, Rutgers University, 6959 Miller Ave., Port Norris, NJ \\ 08349; ${ }^{3}$ Marine Science Center, University of New England, 1-43 Hills Beach Rd., Biddeford, ME 04005
}

\begin{abstract}
Aquaculture of the northern quahog (=hard clam) Mercenaria mercenaria (Linnaeus, 1758) is widespread in shallow waters of the United States from Cape Cod to the eastern Gulf of Mexico. Grow-out practices generally involve bottom planting and the use of predator exclusion mesh. Both the extent and scale of clam farms have increased in recent decades resulting in concerns regarding the impacts of these practices on estuarine fauna. Seasonal distribution, abundance, biomass, species richness, and community composition of nektonic, demersal, epibenthic, and infaunal organisms were examined in cultivated and uncultivated shallow-water habitats in Virginia and New Jersey. The results reveal that clam aquaculture, as practiced in both Virginia and New Jersey, has remarkably few quantifiable impacts on estuarine fauna. Seasonal variations were observed in the biota, but of the 39 population and community metrics tested, mean values associated with 26 did not differ between cultivated and uncultivated areas, 5 had decreases and 8 had increases. For recently harvested areas, 32 of 39 variables were not different from uncultivated areas, 6 decreased in at least one season, and 1, blue crab biomass, had a marginal increase. Decreases were observed in the abundance and biomass of infauna (exclusive of the cultured clams) on clam farms, including in harvested areas, relative to natural uncultivated areas. This was accompanied, however, by substantial increases in epibenthic macroalgae, which in some cases supported increased epifaunal species richness and abundance relative to uncultivated areas. Habitat use by finfish, crustaceans, and terrapins was largely unaffected by the presence of clam farms.
\end{abstract}

KEY WORDS: clam aquaculture, Mercenaria mercenaria, ecological effects, nekton, benthos

\section{INTRODUCTION}

Aquaculture production of northern quahog (=hard clam) Mercenaria mercenaria along the Atlantic and Gulf of Mexico coasts of the United States has grown dramatically over the past $25 \mathrm{y}$, with current production exceeding \$59 M (National Agricultural Statistics Service 2014). Production occurs in shallow subtidal and intertidal soft-sediment habitats where clams are planted in the sediments and generally covered with predator exclusion nets. With the expansion of this industry has come an interest in the ecological effects associated with clam production in these shallow coastal environments. Although there have been a substantial number of studies on the ecological effects of suspended and epifaunal bivalve culture (see NRC 2010 for a recent compilation), less is known about the ecological effects of the culture of infaunal bivalves. Early studies on clams (Menzel \& Sims 1964, Castagna 1970, Walne 1974, Menzel et al. 1975 Castagna \& Kraeuter 1977, Kraeuter \& Castagna 1977, 1980, 1985a, 1985b, 1989, Miller et al. 1978, Glock \& Chew 1979, Anderson \& Chew 1980, Anderson 1982, Anderson et al. 1982, Spencer et al. 1991, 1992, Toba et al. 1992) examined the effects of bottom netting and other means of predator protection in the success of growing clams from seed to market size.

More recent studies have revealed that intensive aquaculture of infaunal clams can alter bottom habitats, affect benthic and demersal communities, and alter biogeochemical processes. Several studies have revealed enhanced sedimentation rates, reduced grain size, and/or increased sediment organic content associated with clam culture (Mojica \& Nelson 1993, Spencer et al. 1996, 1997, 1998, Goulletquer et al. 1999, Jie et al. 2001, Munroe \& McKinley 2007), whereas others have reported

*Corresponding author. E-mail: luck@vims.edu DOI: $10.2983 / 035.035 .0405$ changes in nutrient dynamics (Bartoli et al. 2001, Nizzoli et al. 2006, 2011, Murphy et al. 2015). In general, these studies have shown moderate organic enrichment of bottom sediments, enhanced nutrient regeneration and, in contrast to suspended mussel culture, little or no hypoxia generation (Nizzoli et al. 2006, 2011, Murphy et al. 2015).

Other studies have investigated the effects of clam aquaculture on infaunal, epifaunal, and demersal assemblages (Whiteley \& Bendell-Young 2007, Kaiser et al. 1996, 1998, Powers et al. 2007, Dumbauld et al. 2009, Coen et al. 2011, McDonald et al. 2015, VanBlaricom et al. 2015). These studies reveal that aquaculture activities — planting and harvesting — serve as pulse disturbances and recovery rates of most faunal assemblages are on the order of 1 mo to $1 \mathrm{y}$, depending on the scale of the disturbance and the availability of new recruits (Kaiser et al. 1998). Increased abundance of infaunal groups also has been observed in clam culture sites relative to uncultivated control sites (gammarid amphipods and nemertean worms: Thompson 1995; deposit-feeding polychaetes: Spencer et al. 1996, 1998). Predator exclusion nets have been found to create a "reef effect" by enhancing abundance of both macroalgae and epifauna (Powers et al. 2007, Dumbauld et al. 2009, McDonald et al. 2015, VanBlaricom et al. 2015). Powers et al. (2007) observed comparable abundances of juvenile fishes and motile invertebrates associated with macroalgae on a clam farm and nearby seagrass habitat, both of which exceeded the abundances observed on adjacent sandflat habitat. This result is similar to that found for geoduck farming, where few long-term effects due to the tubing and net systems used for planting or the disturbance caused by subsequent harvest have been observed (McDonald et al. 2015, VanBlaricom et al. 2015). Here, too, the major difference in fauna was the "reef effect" with gear increasing the abundance of transient epifauna (McDonald et al. 2015). These studies leave unresolved the question of the 
net effect of clam culture on estuarine fauna. This study examined the effects of aquaculture practices for the hard clam Mercenaria mercenaria on the ecology of shallow-water habitats, specifically, the seasonal distribution, abundance, biomass, species richness, and community composition of nektonic, demersal, epibenthic, and infaunal organisms in cultivated and uncultivated shallowwater habitats in Virginia and New Jersey. The overall goal was to understand how clam farms affect estuarine fauna to support the development of best management practices and sustainability of the industry.

\section{MATERIALS AND METHODS}

\section{Study Sites}

Studies were carried out on two commercial hard clam (Mercenaria mercenaria) farms: one in Dry Bay, New Jersey, and the other in Cherrystone Creek, Virginia (Fig. 1A). The Dry Bay site is surrounded by Spartina marshes in a tidal embayment situated in the mid-New Jersey coast on the mainland side of a barrier island/bay lagoon system. It is immediately adjacent to the Brigantine Division of the Edwin B. Forsythe National Wildlife Refuge, and has been a site of clam aquaculture since the mid-1970s. The average depth is less than $2 \mathrm{~m}$, and on all but the most extreme low tide the area is covered by about $0.25 \mathrm{~m}$ of water. Most of the embayment is leased for clam cultivation and there are 157 leases totaling about 370 acres $\left(1.5 \mathrm{~km}^{2}\right)$. The study site was near the backside of the lease areas and is operated by Mathis and Mathis Enterprises. There were approximately 100 plots on this lease. As is typical in New Jersey, each bed is covered by a polyethylene predator exclusion net measuring $\sim 4.2 \mathrm{~m} \times$ $5.1 \mathrm{~m}$. After the first winter, these nets are removed for the winter and replaced in the spring to avoid ice damage.

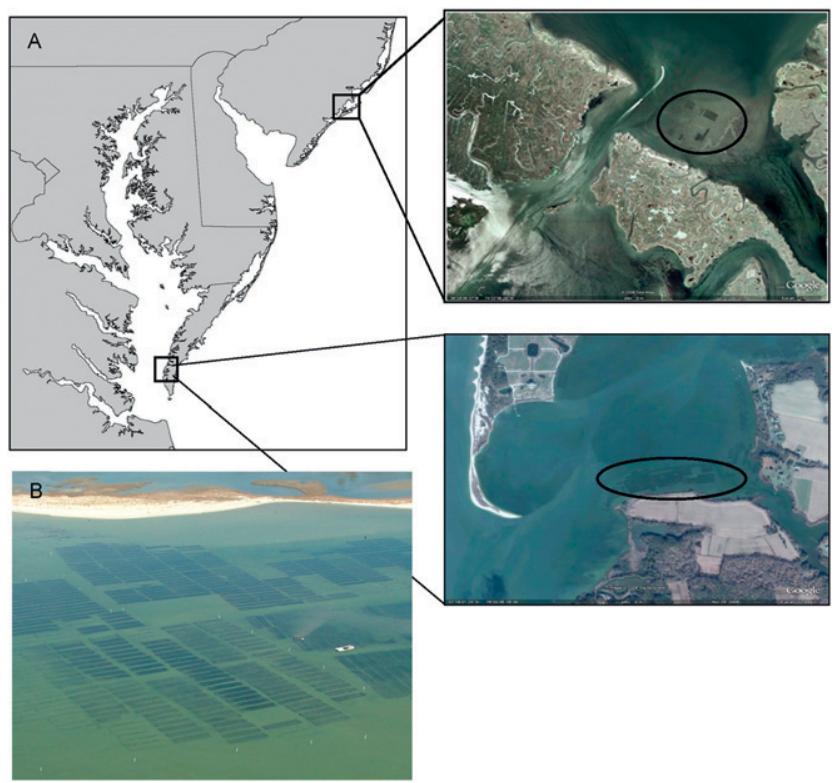

Figure 1. (A) Sample locations in Dry Bay, NJ, and Cherrystone Creek, VA. Clam farms are circled. (Aerial photographs are not to the same scale.) (B) Portion of clam farm in Cherrystone Creek, VA, showing areas under cultivation (dark colored nets), recently harvested habitats (light color, outline of nets visible), and areas that are uncultivated. Shallow subtidal areas outside of the farm were used as uncultivated habitats.
The Cherrystone Creek, VA, site is a small tidal embayment on the southeastern margin of Chesapeake Bay. This shallow embayment, with an average depth of less than $2 \mathrm{~m}$, is a productive clam-growing area and one-third $\left(1.9 \mathrm{~km}^{2}\right)$ of the subtidal bottom area is held as 37 separate, private shellfish leases. The study site, leased and operated by Cherrystone AquaFarms Inc., is one of the largest clam farms in Virginia, with over 1,000 individual beds, each measuring approximately $4 \mathrm{~m} \times 17 \mathrm{~m}$. As in New Jersey, polyethylene predator exclusion nets cover these beds.

\section{Study Design}

Sampling was conducted during the spring, summer, and fall of 2009. At each site, working in collaboration with the farmer, three bottom types were identified: (1) cultivated $=$ habitats with nets covering clams greater than 6 mo old; (2) recently harvested $=$ habitats formerly covered by nets, but harvested within the previous $1.5 \mathrm{mo}$; (3) uncultivated $=$ habitats adjacent to the clam farms with similar water depth and bottom type, but without nets or structures (Fig. 1B)

Motile fauna were collected in the three habitat types using fyke nets and haul seines in a series of day/night samplings at three times (spring, summer, and fall 2009) at both locations. Three replicates of each habitat type were selected from the available habitats on each clam farm. One replicate of each bottom type was sampled per day over a 3-day period with an array of three fyke nets designed to sample organisms moving over clam nets (Fig. 2). The fyke nets were made of $12.7-\mathrm{mm}$ mesh and had 3-m-long wings $1.2-\mathrm{m}$ high that funneled into a $0.9 \times 0.9 \mathrm{~m}$ mouth opening. Two nets were arranged along the long axis of a clam bed and connected via a leader net; a third net was arranged perpendicular to these nests, with its leader net extending toward the center line between the other two nets. The fyke nets were deployed for 24-h periods to capture organisms using each habitat type during day and night over varying tidal stages. The entire sampling procedure was repeated over three consecutive days to provide three replicates of each habitat type. All organisms caught in the fyke nets were identified to species, measured, and total wet weight for the species recorded in the field. A few individuals of each species were kept as voucher specimens and others were released at the site. Individual wet weights and length measures were recorded for selected species.

At separate locations within each farm, hand-towed haul seines of 4.8-mm knotless mesh $6-\mathrm{m}$ wide $\times 1.2-\mathrm{m}$ high with a 1.2-m-long cod-end bag were used to sample different components of the motile biota. A total of three replicate daytime tows were collected near low tide from each habitat type during each sample season. In New Jersey, the seines were towed for $6 \mathrm{~m}$ across the clam habitats. In Virginia, the initial tows taken in the spring were $15 \mathrm{~m}$ long; however, during the summer and fall when macroalgal biomass on the nets was greater, seine tows were shortened to $11 \mathrm{~m}$. To facilitate comparisons of seine data between the two states, abundance and biomass data from seine samples in Virginia were normalized to 6-m tows. All samples were collected in fine mesh bags, preserved, sorted, identified to the lowest possible taxon, and dry weights of selected groups measured.

Benthic macroalgae are often present in high abundance on the nets covering actively growing clams. The attached macroalgae can provide habitat for numerous macrobenthic organisms 

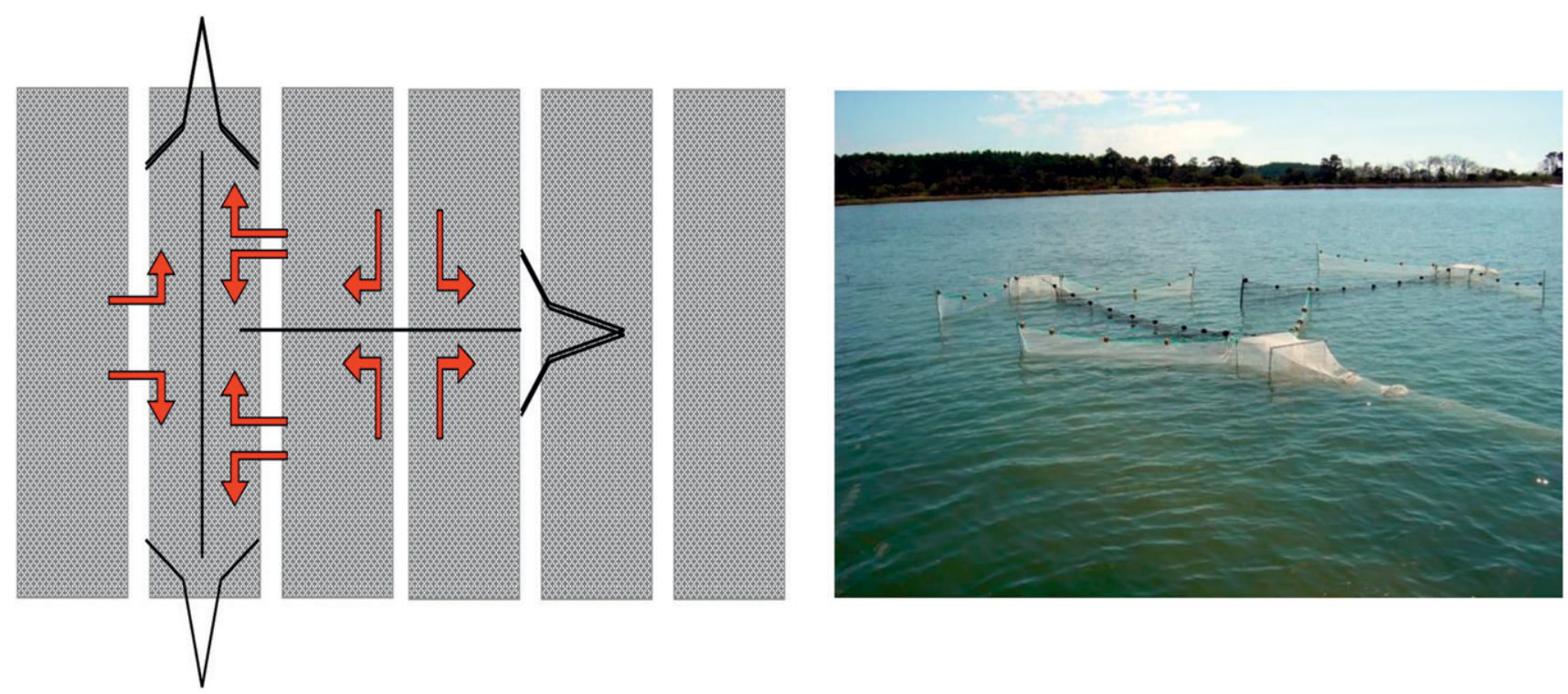

Figure 2. Diagram of fyke net sampling arrangement over clam nets. Hatched areas indicate clam nets; $\succ$ represents fyke nets; horizontal and vertical lines represent leader nets that direct fish into the fyke nets and red arrows indicate generalized fish movement patterns in response to the nets. Similar net arrays were placed over recently harvested beds and control areas.

that are not readily caught in the fyke nets, or haul seine samples. Thus, during each of the seasonal sampling events, this macroalgae and associated fauna were quantitatively sampled by placing a 30.5-cm-diameter cylinder on the net surface and a suction sampler with a $2-\mathrm{mm}$ mesh bag was used to remove all of the contents. This sampling gear is similar to that used by Powers et al. (2007) to sample similar habitats. Five haphazardly located replicate samples were collected from each of three replicate nets covering clams greater than 6 mo old. Fifteen samples were similarly collected from both recently harvested and uncultivated habitats, with care taken to suction sample only the top few centimeters of surficial sediments. Algae were separated from the fauna, identified to the lowest possible taxon, and total dry weight biomass determined. Fauna were preserved, identified to the lowest possible taxon, enumerated, and biomass determined for major taxa groupings.

Deeper dwelling macrobenthic organisms were sampled using 10-cm-diameter cores to a depth of $15 \mathrm{~cm}$ during the fall sample period only in the three habitats (cultivated, recently harvested, and uncultivated); in New Jersey, additional samples were also collected from recently planted ( $<3$ mo. old $)$ beds, and in Virginia, samples were taken in the rows between the beds. Three replicates of each habitat type were randomly selected, nets were temporarily removed from the cultivated habitats and six haphazardly located replicate cores were collected. Contents of each core were sieved on a 1-mm mesh sieve and all macrofauna (including the clams) retained on the sieve were preserved, identified to the lowest possible taxon, and dry weight biomass determined for major taxa groupings (clams, other bivalves, other molluscs, arthropods, annelids, and others).

Temperature, salinity, and dissolved oxygen were recorded on each sampling date with a YSI meter.

\section{Data Analysis}

The data sets from Virginia and New Jersey were analyzed separately for several reasons. First, clam farms at the two sites were quite different. In New Jersey, the predator exclusion nets were considerably shorter $(\sim 6 \mathrm{~m})$ than those in Virginia $(\sim 15-$ $18 \mathrm{~m})$, and the farms differed considerably in the number of beds, approximately 100 beds in New Jersey and over 1,000 in Virginia. Second, regional differences in taxa make direct comparisons less appropriate. Finally, initial joint analyses of some of the data made it apparent that most such analyses would result in significant interaction terms, necessitating that the data sets be parsed for separate analyses.

For the fyke net, seine, and suction sample, two-way, fixed factor analysis of variance (ANOVA) data were used to evaluate the effects of habitat type and season on response variables, including overall abundance, biomass, and species richness. When assumptions of normality and homoscedasticity were not met, the data were transformed using natural log and square root transformations and tested again. If assumptions were still not met, nonparametric Kruskal-Wallis tests were run on individual main effects. When significant interactions between main effects were observed in two-way ANOVA, the dataset was parsed and the effects of habitat type within each season and the effects of season within each habitat type were tested separately using one-way ANOVA or Kruskal-Wallis tests as appropriate. Tukey's pairwise multiple comparison tests, with an experiment-wise error rate equal to 0.05 , were used post hoc to determine differences between means when significant main effects were observed.

Benthic core samples for infaunal macrobenthic invertebrates were collected only during the fall, so one-way ANOVA or Kruskal-Wallis tests, as appropriate, used to test for the effects of habitat type on abundance, biomass, and species richness. Tukey's pairwise multiple comparisons tests were again used to evaluate difference between pairs of means.

To compare finfish, epifaunal, and infaunal community compositions across habitat type, nonmetric multidimensional scaling (nMDS) was performed on square root transformed data using Bray-Curtis similarity matrices, followed by analysis of similarity (ANOSIM) to evaluate the significance of observed patterns. When differences in community composition were indicated by 
ANOSIM, similarity percentage analysis was performed to identify the species primarily responsible for differences across habitats. Each of these analyses was performed using PRIMER software.

\section{RESULTS}

Over 23,000 individual organisms were collected and 137 taxa were identified, mostly to species level, across all habitats, gear types, and seasons throughout the study (Appendix, Table A1).

\section{Physical Data}

Tide data collected from nearby NOAA tide gages indicated that tidal amplitude was greater at the New Jersey site $(1.07 \mathrm{~m}$ neap, $1.22 \mathrm{~m}$ spring) than the Virginia site $(0.70 \mathrm{~m}$ neap, $0.85 \mathrm{~m}$ spring). Temperatures were slightly warmer at Virginia and salinities were more variable at the New Jersey site (Table 1). Dissolved oxygen was similar in the spring and fall at both sites, and both experienced a drop in oxygen during the summer.

\section{Nekton and Demersal Fauna}

Over 11,600 individual organisms were caught in all gear used to collect nekton and demersal fauna (fyke nets and haul seines) over the course of the study. Forty-three species of fish, 18 species of decapods, and 1 species of reptile were identified among these specimens across the two study areas (Appendix, Table A1). Because each gear type generally collected different species, the findings are presented below by gear type for both the New Jersey and Virginia sites.

\section{Fyke Net Samples}

\section{Species Richness}

The mean number of species captured during a 24-h sample period in the fyke net arrays ranged between 3.7 for the uncultivated site in New Jersey during the fall to 14.7 for the uncultivated site in Virginia during the summer. Species richness in Virginia varied significantly by season with greater values in summer than either the fall or spring. Neither habitat type nor the interaction between habitat type and season had a significant effect on species richness in the Virginia samples (Table 2). In New Jersey, species richness in the fyke net samples also varied by season, but in this case both summer and spring samples had higher species richness than the fall samples. There was no significant effect of habitat type or its interaction with season on species richness in New Jersey (Table 2).

\section{Finfish}

Finfish abundance patterns in the fyke net samples differed markedly between Virginia and New Jersey (Fig. 3). Abundances in Virginia were at their lowest during the spring sampling period with marked increases observed in all habitats in the summer and fall. In contrast, in New Jersey, finfish abundances remained relatively low through the spring and summer before increasing in the fall (Fig. 3). In Virginia, the numerically dominant fish species varied with season, with the American eel Anguilla rostrata (Lesueur, 1817), followed by the Atlantic silverside Menidia menidia (Linnaeus, 1766), the most abundant fish in the spring. In summer spot, Leisotomus xanthurus (Lacepede, 1802) were abundant in all habitats, but silver perch Bairdiella chrysoura (Lacepede, 1802) were more abundant over uncultivated habitats than either the clam or harvested sites (ANOVA: $F=115, P<0.001$ ). By fall, silver perch became the most abundant fish species over all areas with more being caught over the clam habitat. In New Jersey, silver perch were the most abundant fish across all habitat types in all seasons. In spring, the American eel was the second most abundant fish in each habitat, but during summer and fall, small black sea bass Centropristes striatus (Linnaeus, 1758) became the second most abundant species, and generally occupied all habitats equally.

A significant interaction was observed between habitat type and season on total fish abundance in Virginia. One-way ANOVA for the effect of season on finfish abundance revealed differences only in the uncultivated habitat where fall abundances exceeded summer abundances that in turn exceeded spring abundances (Table 2). During the summer, finfish abundance in the uncultivated habitat exceeded that observed in the clam habitat in Virginia (Table 2). For the New Jersey data, finfish abundance varied with season, but not with habitat or the interaction of the two, with abundances in the fall exceeding those in the summer and spring (Table 2).

The average length of finfish captured in the fyke nets, which largely reflects the seasonal changes in species composition, also varied across season at the two study sites (Table 2). The larger mean size of fish caught in the spring in Virginia and the spring and summer in New Jersey reflects a greater abundance of American eels at those times. No effect of habitat type on fish length was observed in Virginia or New Jersey. Fish wet weight biomass (measured only in New Jersey) was lower in the summer

TABLE 1.

Physical parameters from each of the two study sites.

\begin{tabular}{|c|c|c|c|}
\hline Sample dates & Seawater temperature $\left({ }^{\circ} \mathrm{C}\right)$ & Salinity & Dissolved oxygen (mg/l) \\
\hline \multicolumn{4}{|c|}{ New Jersey } \\
\hline April 23-16 & $12.9-17.7$ & $19.5-26.5$ & $6.3-8.6$ \\
\hline August 4-6 & $25.1-26.8$ & $22.4-26.0$ & $2.2-3.4$ \\
\hline October $12-15$ & $12.0-16.0$ & $26.4-26.9$ & 6.2 \\
\hline \multicolumn{4}{|c|}{ Virginia } \\
\hline April 7-9 & $10.4-14.3$ & $21.7-22.4$ & $6.0-8.0$ \\
\hline July 20-22 & $27.4-29.3$ & $22.1-22.6$ & $4.3-6.5$ \\
\hline October $26-28$ & $15.1-17.4$ & $22.1-22.8$ & $5.6-6.8$ \\
\hline
\end{tabular}

Ranges for T, S, and DO are for the 3-day sampling period within each season. 
TABLE 2.

Summary of statistical analyses of Fyke net data in VA and NJ in three seasons over three habitats.

\begin{tabular}{|c|c|c|c|c|}
\hline Dependent variable & Season & Habitat & Season $\times$ habitat & Post hoc summary \\
\hline \multicolumn{5}{|l|}{ Species richness } \\
\hline VA & & 0.188 & 0.217 & $\mathrm{Su}>\mathrm{Sp}=\mathrm{F}$ \\
\hline NJ & $<0.0010 .002$ & 0.924 & 0.142 & $\mathrm{Su}=\mathrm{Sp}>\mathrm{F}$ \\
\hline \multicolumn{5}{|l|}{ Fish abundance } \\
\hline \multirow[t]{3}{*}{ VA } & $C: 0.093$ & Sp: 0.713 & & $\mathrm{Su}: \mathrm{Uc}>\mathrm{C}, \mathrm{Uc}=\mathrm{H}, \mathrm{H}=\mathrm{C}$ \\
\hline & H: 0.207 & Su: 0.041 & & $\mathrm{Uc}: \mathrm{Su}>\mathrm{F}>\mathrm{Sp}$ \\
\hline & Uc: $<0.001$ & F: 0.203 & & $\mathrm{~F}>\mathrm{Su}=\mathrm{Sp}$ \\
\hline NJ & $<0.001$ & 0.197 & 0.515 & \\
\hline \multicolumn{5}{|l|}{ Fish biomass } \\
\hline NJ & 0.036 & 0.699 & 0.909 & $\mathrm{Sp}>\mathrm{Su}, \mathrm{Sp}=\mathrm{F}, \mathrm{F}=\mathrm{Su}$ \\
\hline \multicolumn{5}{|l|}{ Fish length } \\
\hline VA & 0.007 & 0.611 & 0.749 & $\mathrm{Sp}>\mathrm{Su}=\mathrm{F}$ \\
\hline NJ & 0.001 & 0.473 & 0.833 & $\mathrm{Sp}=\mathrm{Su}>\mathrm{F}$ \\
\hline \multicolumn{5}{|l|}{ Crustacean abundance } \\
\hline VA & $<0.001$ & 0.436 & 0.938 & $\mathrm{Su}>\mathrm{F}=\mathrm{Sp}$ \\
\hline $\mathrm{NJ}$ & $<0.001$ & 0.091 & 0.475 & $\mathrm{Sp}>\mathrm{Su}>\mathrm{F}$ \\
\hline Blue crab biomass ( $\mathrm{NJ}$ only) & 0.027 & 0.032 & 0.964 & $\mathrm{C}=\mathrm{H}=\mathrm{Uc}$ \\
\hline Diamond back terrapin abundance ( $\mathrm{NJ}$ only) & $<0.001$ & 0.948 & 0.475 & $\begin{array}{l}\mathrm{Sp}>\mathrm{F} \mathrm{Sp}=\mathrm{Su}, \mathrm{Su}=\mathrm{F} \\
\mathrm{Su}>\mathrm{Sp}=\mathrm{F}\end{array}$ \\
\hline
\end{tabular}

Sp, spring; Su, summer; F, fall; C, clam plot; H, harvested plot; Uc, uncultivated area; VA, Virginia; NJ, New Jersey. Values are P values from twoway ANOVA, when interactions were nonsignificant; otherwise, results are from a series of one-way ANOVA. Inequalities in the post hoc tests indicate $P$ values $\leq 0.05$.

than in the spring. There were no significant effects of habitat type or its interaction with season on fish biomass (Table 2).

\section{Fish Community Structure}

Nonmetric multidimensional scaling plots revealed clear differences in fish community structure in Virginia across season, but no clear pattern across habitat type (Fig. 4A). Analysis of similarity confirmed these differences among seasons $(R=0.83$, significance level $=0.1 \%)$. In contrast, fish community composition over clam nets and uncultivated sites had only modest levels of dissimilarity $(R=0.48$, significance level $=1.3 \%$ ), whereas fish communities were very similar over clam nets and harvest sites $(R=0.21$, significance level $=4.0 \%)$ and harvest sites and uncultivated sites $(R=0.20$, significance level $=9.4 \%$ ). Similarity percentage analysis revealed that the modest differences in fish community structure over clam nets and uncultivated sites were driven by slightly greater abundances of silver perch, American eel, hogchoker, menhaden, and summer flounder over uncultivated areas relative to clam nets.

For the New Jersey data, nMDS plots (Fig. 4B) and ANOSIM revealed differences in fish community structure among seasons $(R=0.58$, significance level $=0.1 \%)$, but not between habitat type $(R=-0.04$, significance level $=64.4 \%)$.

\section{Crustaceans}

Dominant species of crustaceans captured in the fyke nets included the blue crab Callinectes sapidus (Rathbun, 1896) and grass shrimp Palaemonetes spp. Seasonal patterns of crustacean
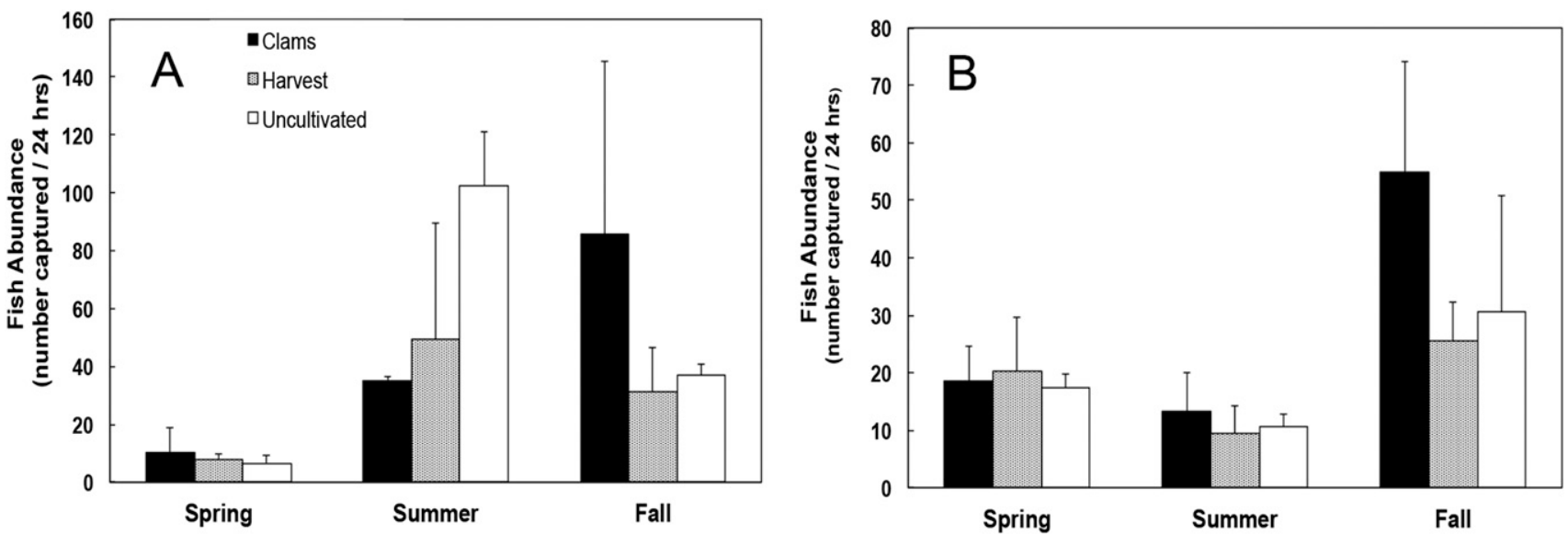

Figure 3. Mean finfish abundance (number captured/24 h) in fyke net arrays over each bottom type by season in (A) Virginia and (B) New Jersey. Error bars are $+1 \mathrm{SD}(n=3)$. Clams = cultured bottom with nets covering clams planted for more than 6 mo. Harvest $=$ clam beds that were harvested within the past 45 days. Uncultivated = natural bare substrate or "control" area. Note scale difference. 

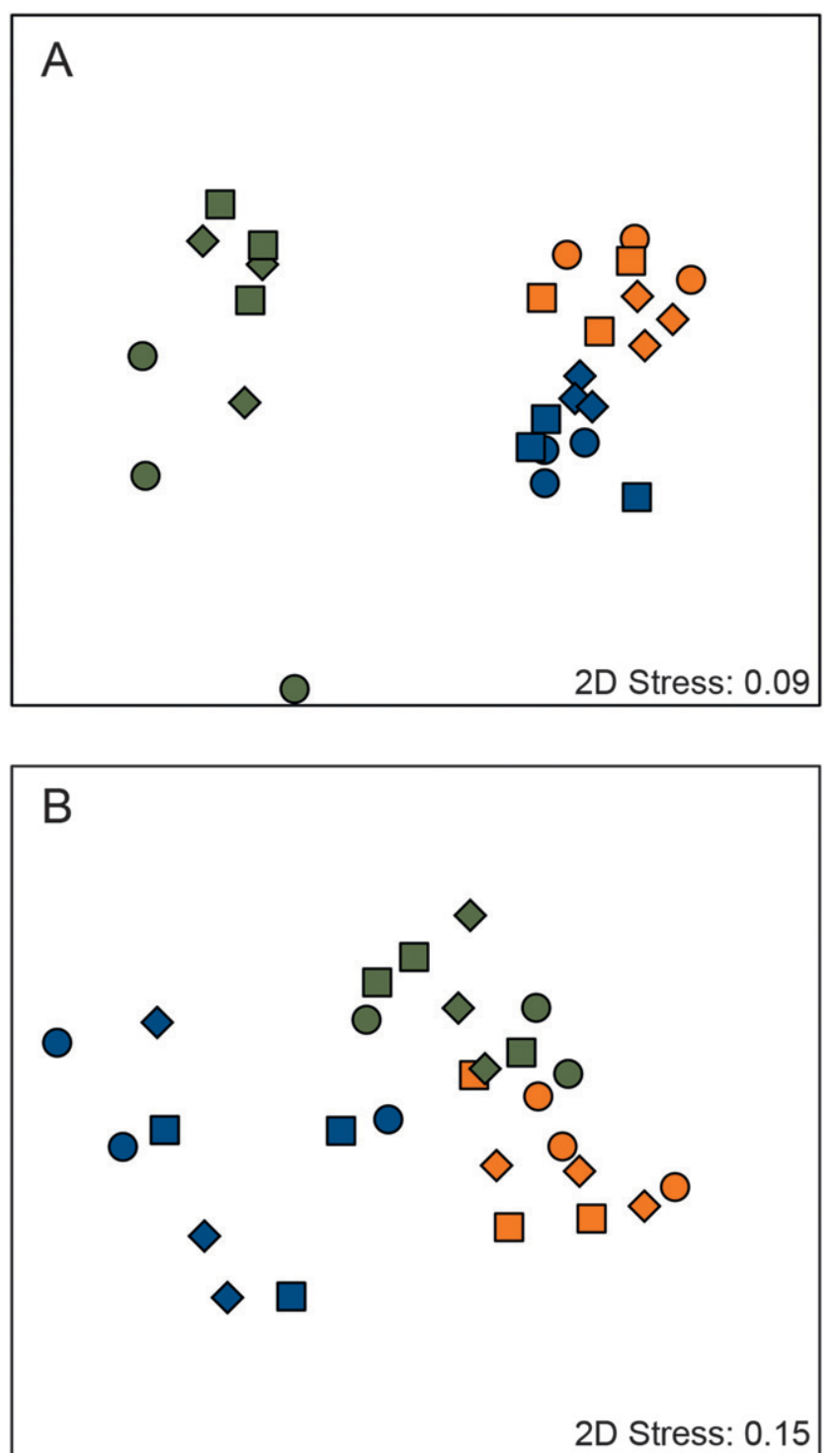

Figure 4. Two-dimensional nMSD plot of fish community (as captured by fyke nets) similarity based on square root-transformed abundance data between habitat types by season in (A) Virginia and (B) New Jersey. Circles $(\bullet)$ indicate cultivated sites, squares $(\square)$ indicate cultivated sites that have been harvested within the previous $6 \mathrm{wk}$, and diamonds $(\diamond)$ indicate uncultivated sites. Green symbols indicate samples taken during spring, blue during summer, and orange during fall.

abundance varied between Virginia and New Jersey. In Virginia, there was no effect of habitat type or its interaction with season on the mean abundance of crustaceans, but there was a significant effect of season, with summer having greater abundances than either spring or fall (Table 2). In New Jersey, there was a nonsignificant trend of greater crustacean abundance in the harvested sites than in either the clam beds or uncultivated sites, and there was no interaction between habitat type and season. Crustacean abundance varied significantly with season, with significantly greater abundances in the spring compared with the summer and fall (Table 2). Wet weight biomass of blue crabs caught in the fyke net arrays (New Jersey only) varied with habitat type and season, but not the interaction between these factors (Table 2). Post hoc multiple comparisons were unable to distinguish differences between pairwise combinations of habitat type means (Table 2); however, it is evident from inspection of the data that the greater blue crab biomass in samples from harvested areas was responsible for observed differences. Significantly greater blue crab biomass was collected in the spring than the fall, with comparable amounts in the spring and summer (Table 2).

\section{Diamondback Terrapins}

Though not a target species in the sampling regime, diamondback terrapins [Malaclemys terrapin (Schoepf, 1793)] were captured in fyke net samples during all seasons at the New Jersey site with mean abundance peaking at 25 individuals in the summer. None were caught at the Virginia site during this study; however, in subsequent sampling on this clam farm in Virginia, Luckenbach has caught this species in similar fyke net arrays. In New Jersey, there was no interaction between season and habitat type nor an effect of habitat type on terrapin abundance, but there was a significant effect of season, with summer having greater numbers than either the spring or fall (Table 2).

\section{Seine Samples}

\section{Species Richness}

The average number of species caught in the seine samples varied from a low of 2.2 over the uncultivated bottom in Virginia during the spring to 9.0 over recently harvested bottom habitat in Virginia during the summer. Species richness varied significantly with season in Virginia, the summer having higher values than either the fall or spring. No significant variation between habitat types was observed in Virginia nor was there a habitat type by season interaction. In New Jersey there were no significant effects of either season or habitat type or their interactions on species richness in seine samples (Table 3).

\section{Finfish Abundance}

Numerically dominant fish caught in the seine net in Virginia were silver perch, Atlantic silversides, and bay anchovies [Anchoa mitchilli (Valenciennes, 1848)]. In New Jersey, Atlantic silversides and bay anchovies were the most common fish caught in the seine; silver perch were not caught in New Jersey seine samples. Fish abundances were greater in Virginia than in New Jersey during the summer, but comparable during the fall and lower during the spring. Significant effect of season on fish abundance was observed in both Virginia and New Jersey with greater fish abundance in the summer in Virginia and summer abundances exceeding fall abundances in New Jersey. No significant effect of habitat type on finfish abundance was observed at either location (Table 3).

\section{Crustaceans Abundance}

The numerically dominant crustaceans captured in the seine nets in Virginia were grass shrimp Palaemonetes vulgaris (Say, 1818), Palaemonetes pugio (Holthuis, 1949), and P. intermedius (Holthuis, 1949); broke-backed shrimp Hippolyte pleuracantha (Stimpson, 1871); and juvenile blue crabs. In New Jersey, grass shrimp, equal-clawed mud crabs Dyspanopeus sayi (Smith, 1869), sand shrimp Crangon septemspinosa (Say, 1818), and blue crabs were the numerically dominant crustaceans collected in the seine samples.

A significant interaction was observed between habitat type and season on crustacean abundance in the seine samples from 
TABLE 3.

Summary of statistical analyses of seine net data in VA and NJ in three seasons over three habitats.

\begin{tabular}{|c|c|c|c|c|}
\hline Dependent variable & Season & Habitat & Season $\times$ habitat & Post hoc summary \\
\hline \multicolumn{5}{|l|}{ Species richness } \\
\hline VA & $<0.001$ & 0.182 & 0.733 & \multirow[t]{2}{*}{$\mathrm{Su}=\mathrm{F}>\mathrm{Sp}$} \\
\hline NJ & 0.387 & 0.837 & 0.421 & \\
\hline \multicolumn{5}{|l|}{ Fish abundance } \\
\hline VA* & $<0.001$ & 0.677 & NA & $\mathrm{Su}>\mathrm{F}=\mathrm{S}$ \\
\hline $\mathrm{NJ} \dagger$ & 0.009 & 0.127 & NA & $\mathrm{Su}>\mathrm{F}$ \\
\hline \multicolumn{5}{|l|}{ Crustacean abundance } \\
\hline \multirow[t]{4}{*}{ VAt } & C: 0.006 & Sp: 0.004 & \multirow[t]{4}{*}{0.006} & $\mathrm{C}: \mathrm{F}>\mathrm{Sp}=\mathrm{Su}$ \\
\hline & H: 0.739 & Su: 0.271 & & Uc: $\mathrm{Su}>\mathrm{Sp}=\mathrm{F}$ \\
\hline & Uc: 0.004 & $\mathrm{~F}:<0.001$ & & Sp: C $>$ Uc \\
\hline & & & & $\mathrm{F}: \mathrm{C}>\mathrm{H}=\mathrm{Uc}$ \\
\hline NJ & 0.041 & 0.147 & 0.219 & $\mathrm{Sp}>\mathrm{Su}, \mathrm{Sp}=\mathrm{F}, \mathrm{Su}=\mathrm{F}$ \\
\hline
\end{tabular}

Sp, spring; Su, summer; F, fall; C, clam plot; H, harvested plot; Uc, uncultivated area; VA, Virginia; NJ, New Jersey. Values are $P$ values from twoway ANOVA, one-way ANOVA, and Kruskal-Wallis tests as indicated below. Inequalities in the post hoc tests indicate $P$ values $\leq 0.05$.

* Failed to meet assumptions of normality and equal variances in two-way and one-way models. $P$ values are from Kruskal-Wallis tests.

$\dagger$ Failed to meet assumptions of equal variances in two-way model. $P$ values are from separate one-way ANOVA.

$\ddagger$ Significant season $\times$ habitat interaction. $P$ values are from separate one-way ANOVA.

Virginia, so separate one-way ANOVA were run for the effects of habitat type within each season and the effects of season within each habitat type. For three of the six one-way analyses, the data failed to meet the assumption of normality, so nonparametric Kruskal-Wallis tests were run (Table 3). The results reveal that in the spring, areas with clams had greater abundance of crustaceans than uncultivated areas, with all other pairwise comparisons between habitat types being equal. Despite the high mean abundance of crustaceans found in uncultivated areas in the summer (Fig. 5A), no significant difference was observed between habitat types (Table 3) in Virginia, a result of high variation in the numbers of grass shrimp collected per tow. Significantly greater crustacean abundance was observed in fall seine samples from the clam areas than either the harvested or uncultivated areas (Table 3). The greater abundance of crustaceans in clam culture areas was driven by the high abundances of Palaemonetes vulgaris and Hippolyte pleuracantha at these locations. Within clam beds in Virginia, the seasonal abundance of crustaceans varied by season with fall having a greater abundance than spring and summer (Table 3). The abundance of crustaceans in the harvested areas did not vary across season in Virginia. At the uncultivated sites, abundances in summer were greater than those observed in the spring and fall (Table 3).

A significant effect of season on crustacean abundance was observed in seine samples from New Jersey, with abundances in the spring exceeding those in the summer and all other pairwise comparisons were nonsignificant. There were no significant habitat types or interactive effects (Table 3 ). The relatively higher abundances of crustaceans in clam bed areas during the spring and fall in New Jersey (Fig. 5B) are attributable to grass shrimp and sand shrimp, but these were patchily distributed between replicate tows resulting in high variance and a lack of statistical difference between habitat types. The apparently greater abundance of crustaceans in the harvested areas during the summer in New Jersey (Fig. 5B) is the result of a single sample having 198 equal-clawed mud crabs.
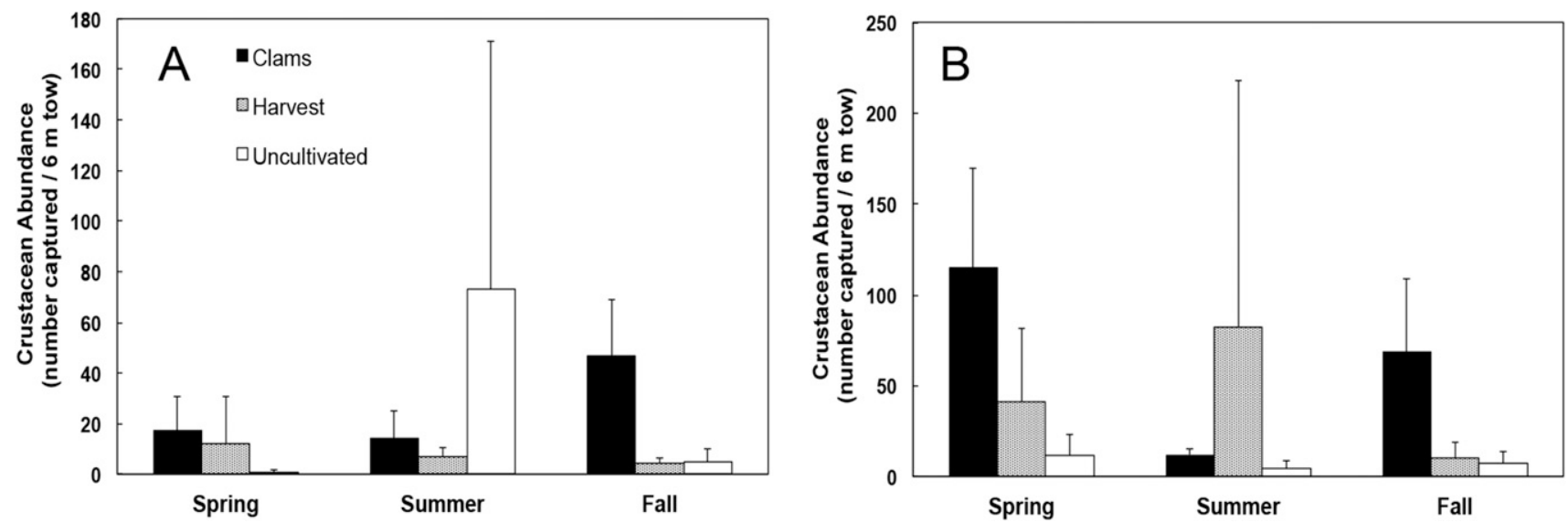

Figure 5. Mean crustacean abundance (number captured/6 $\mathrm{m}$ tow) in seine net samples over each bottom type by season in (A) Virginia and (B) New Jersey. Note scale difference. Labels and error bars as in Figure 3. 
Macroalgae, Epifauna, and Infauna

\section{Suction Samples}

In the clam habitats, suction samples collected macroalgae on net surfaces and the associated epifauna. The nets largely restricted the collection of infaunal benthos. In contrast, at the harvested and uncultivated sites, these samples collected the epibiota and incidentally some shallow infaunal macrobenthic invertebrates. Though referred to as epifauna in the following sections, some of these samples include shallow infauna.

\section{Epifaunal Species Richness}

The mean number of epifaunal species collected in the suction samples ranged from a low of 1.4 in harvest areas in Virginia during the spring to a high of 14.3 at uncultivated areas in New Jersey during the spring (Fig. 6A, B).

Two-way ANOVA for the effects of habitat type and season on species richness in the suction samples from Virginia revealed a significant interaction between main effects, so the data were parsed and separate one-way ANOVA were run for the effects of habitat type within each season and the effects of season within each habitat type (Table 4). There was a significant difference in species richness between habitat types with clam culture areas having greater richness than the harvested and uncultivated areas (Table 4, Fig. 6A). Analysis of variance revealed a significant effect of habitat type during the summer, but Tukey's test failed to detect a significant difference between the habitats. During the fall, the same pattern was observed as in the spring with significantly higher species richness on the clam nets compared with the harvested and uncultivated areas (Table 4). Clam nets had significantly greater species richness during the fall than in other seasons (Table 4, Fig. 6A). Though seasonal variation in species richness at the harvested and uncultivated areas was observed, these differences were not statistically significant.

In New Jersey, epifaunal species richness varied across season with spring and fall values being significantly greater than those in the summer. There was no significant effect of either habitat type or the interaction between season and habitat type on species richness (Fig. 6B, Table 4).

\section{Epifaunal Abundance}

The numerically dominant epifauna collected from clam nets in Virginia were amphipods Gammarus mucronatus (Say, 1818) and Melita sp.; a decapod the broke-backed shrimp; and two small gastropods the black-lined triphora Marshallora nigrocincta (Adams, 1839) and the lunar dove snail Astyris lunata (Say, 1826). In harvested and uncultivated areas in Virginia, the numerically dominant epifauna were two different amphipods, Ampelisca sp. and Corophium sp. and two gastropods, the mud snail Tritia (formerly Ilyanassa) obsoleta (Say, 1822) and the solitary paper bubble Haminoea solitaria (Say, 1822). In New
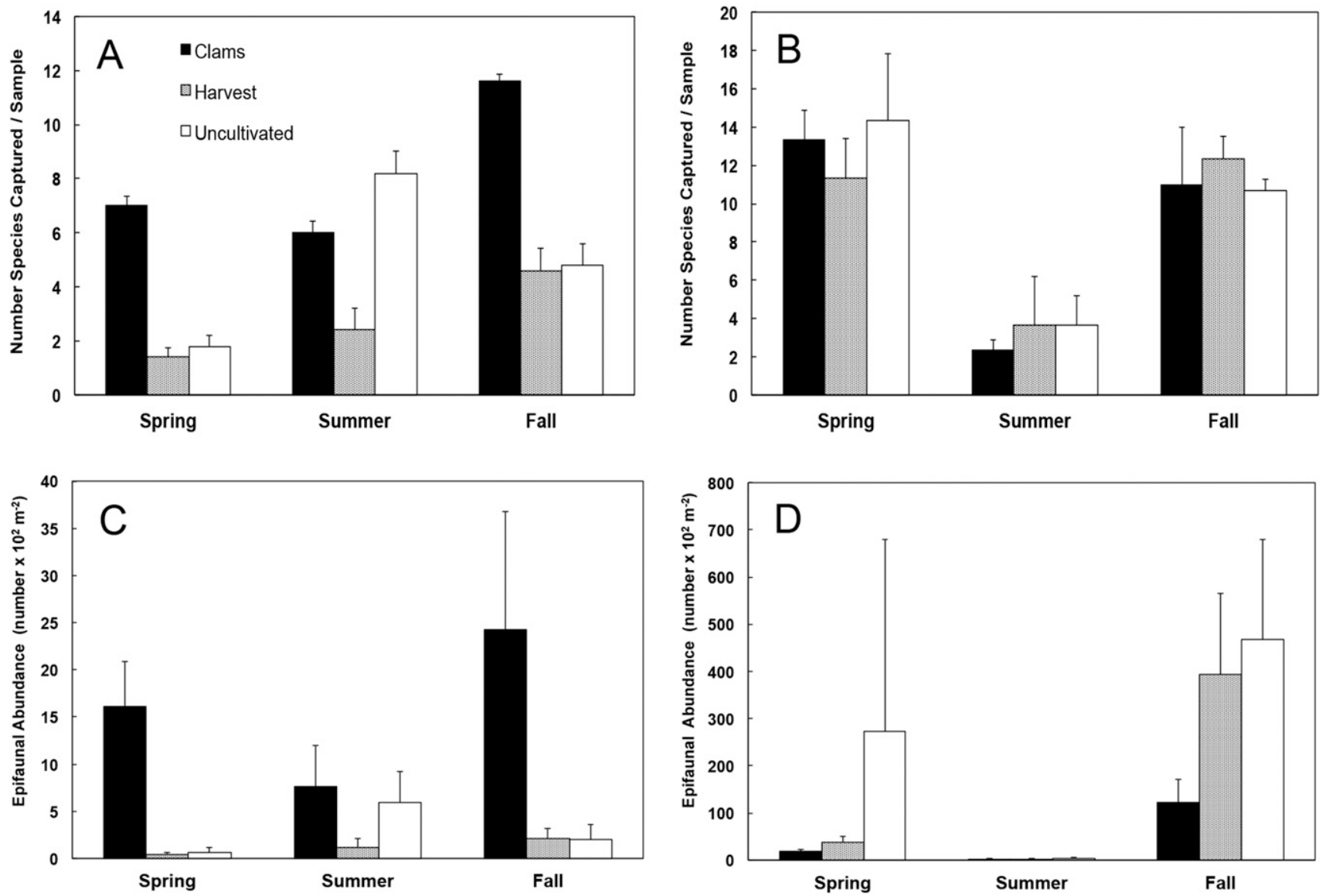

Figure 6. Mean epifaunal species richness in (A) Virginia and (B) New Jersey, and abundance in (C) Virginia and (D) New Jersey by season and habitat type in suction samples. Note the scale difference. Labels and error bars as in Figure 3. 
Effects of Clam Aquaculture on Estuarine Biota

TABLE 4.

Summary of statistical analyses of epibiota data in VA and NJ in three seasons and three habitats.

\begin{tabular}{|c|c|c|c|c|}
\hline Dependent variable & Season & Habitat & Season $\times$ habitat & Post hoc summary \\
\hline \multicolumn{5}{|c|}{ Epifaunal species richness } \\
\hline \multirow{3}{*}{$\mathrm{VA}^{*}$} & C: 0.004 & Sp: $<0.001$ & 0.027 & $\mathrm{C}: \mathrm{F}>\mathrm{Su}=\mathrm{Sp}$ \\
\hline & H: 0.108 & Su: 0.090 & & Sp: $\mathrm{C}>\mathrm{H}=\mathrm{Uc}$ \\
\hline & Uc: 0.081 & $\mathrm{~F}: 0.011$ & & $\mathrm{~F}: \mathrm{C}>\mathrm{H}=\mathrm{Uc}$ \\
\hline NJ & $<0.001$ & 0.741 & 0.593 & $\mathrm{Sp}=\mathrm{F}>\mathrm{Su}$ \\
\hline \multicolumn{5}{|l|}{ Epifaunal abundance } \\
\hline \multirow[t]{2}{*}{ VA } & C: 0.023 & Sp: $<0.001$ & $<0.001$ & $\mathrm{C}: \mathrm{F}>\mathrm{Su}, \mathrm{F}=\mathrm{Sp}, \mathrm{Su}=\mathrm{Sp}$ \\
\hline & H: 0.026 & Su: 0.016 & 0.555 & $\mathrm{H}: \mathrm{F}>\mathrm{Sp}, \mathrm{F}=\mathrm{Su}, \mathrm{Su}=\mathrm{Sp}$ \\
\hline \multirow[t]{6}{*}{ NJ } & Uc: 0.008 & $\mathrm{~F}:<0.001$ & & $\mathrm{Uc}: \mathrm{Su}>\mathrm{Sp}, \mathrm{Su}=\mathrm{F}, \mathrm{Sp}=\mathrm{F}$ \\
\hline & $<0.001$ & 0.017 & & Sp: $\mathrm{C}>\mathrm{H}=\mathrm{Uc}$ \\
\hline & & & & $\mathrm{Su}: \mathrm{C}>\mathrm{H}, \mathrm{C}=\mathrm{Uc}, \mathrm{H}=\mathrm{Uc}$ \\
\hline & & & & $\mathrm{F}: \mathrm{C}>\mathrm{H}=\mathrm{Uc}$ \\
\hline & & & & $\mathrm{Uc}>\mathrm{C}, \mathrm{Uc}=\mathrm{H}, \mathrm{H}=\mathrm{C}$ \\
\hline & & & & $\mathrm{F}>\mathrm{Sp}>\mathrm{Su}$ \\
\hline \multicolumn{5}{|l|}{ Epifaunal biomass } \\
\hline VA & 0.772 & 0.277 & 0.297 & \\
\hline NJ & 0.004 & 0.480 & 0.376 & $\mathrm{Sp}>\mathrm{Su}, \mathrm{Sp}=\mathrm{F}, \mathrm{F}=\mathrm{Su}$ \\
\hline \multicolumn{5}{|c|}{ Macroalgal species richness } \\
\hline \multirow[t]{3}{*}{ VA* } & $\mathrm{C}: 0.013$ & Sp: 0.004 & $<0.001$ & $\mathrm{C}: \mathrm{Su}>\mathrm{F}, \mathrm{Su}=\mathrm{Sp}, \mathrm{Sp}=\mathrm{F}$ \\
\hline & H: 0.879 & Su: $<0.001$ & & Uc: $\mathrm{F}>\mathrm{Sp}, \mathrm{F}=\mathrm{Su}, \mathrm{Su}>\mathrm{Sp}$ \\
\hline & Uc: 0.005 & F: 0.079 & & \\
\hline \multirow[t]{3}{*}{$\mathrm{NJ} *$} & C: 0.005 & Sp: 0.139 & 0.012 & $\mathrm{C}: \mathrm{Sp}>\mathrm{Su}, \mathrm{Sp}=\mathrm{F}, \mathrm{F}>\mathrm{Su}$ \\
\hline & H: 0.079 & Su: 0.068 & & \\
\hline & Uc: 0.579 & F: 0.340 & & \\
\hline \multicolumn{5}{|l|}{ Macroalgal biomass } \\
\hline $\mathrm{VA} \dagger$ & 0.270 & $<0.001$ & & $\mathrm{C}>\mathrm{H}=\mathrm{Uc}$ \\
\hline \multirow[t]{3}{*}{$\mathrm{NJ}^{*}$} & C: 0.065 & Sp: 0.050 & 0.035 & $\mathrm{H}: \mathrm{F}>\mathrm{Sp}=\mathrm{Su}$ \\
\hline & H: 0.002 & Su: 0.680 & & Sp: $\mathrm{C}=\mathrm{H}=\mathrm{Uc}$ \\
\hline & Uc: 0.150 & F: 0.292 & & \\
\hline
\end{tabular}

Sp, spring; Su, summer; F, fall; C, clam plot; H, harvested plot; Uc, uncultivated area; VA, Virginia; NJ, New Jersey. Values are $P$ values from twoway ANOVA, one-way ANOVA, and Kruskal-Wallis tests as indicated below. Inequalities in the post hoc tests indicate $P$ values $\leq 0.05$.

* Significant interaction. One way ANOVA were run when assumption of normality and equal variances were met and Kruskal-Wallis test when they were not.

$\dagger$ ANOVA normality assumptions not met, Kruskal-Wallis test for habitat and season.

Jersey, the numerically dominant epifauna on the clam nets were mysid shrimp Neomysis americana (S.I. Smith, 1873); grass shrimp Palaemonetes vulgaris; the amphipod Ampelisca spp.; and two mud snails, the eastern mud snail T. obsoleta and threeline mud snail Tritia trivitatta (Say, 1822). Harvested and uncultivated sites were dominated by ampeliscid amphipods and mysid shrimp.

Epifaunal abundance patterns in Virginia varied with both habitat type and season (Fig. 6C, Table 4). Two-way ANOVA for the effects of habitat type and season on abundance revealed a significant interaction between the main effects, so the data were parsed and separate one-way tests for the effect of habitat type within each season and the effects of season within habitat type were run (Table 4). Significant effects of habitat type were found in all seasons (Table 4), with clam nets always having the greatest abundance of epifaunal organisms. Seasonal effects were also observed in all habitat types (Table 4), with biggest effects observed on the clam nets. Somewhat surprisingly, the peak abundance of epifauna was observed on the clam nets in the fall when macroalgal biomass was lower than during the spring and summer sampling periods (see section below on Macroalgal Biomass).

In New Jersey, epifauna abundance varied significantly with habitat type and season without any significant interaction
(Table 4). In contrast to Virginia, epifaunal abundance was greatest in uncultivated areas and lowest on clam nets (Fig. 6D). A partial explanation for this difference between the Virginia and New Jersey study sites may lay in the fact that macroalgae is more common in the harvested and uncultivated areas in New Jersey than in Virginia (see section on Macroalgal biomass below), and ampeliscid amphipods dominate abundance numbers by an order of magnitude in New Jersey relative to Virginia. Mysid shrimp were also locally abundant in New Jersey, but were absent in Virginia. At the New Jersey site, ampeliscids form extensive beds of mud tubes, and clam farmers consistently monitor culture areas for these tubes and scrape them clean as necessary. The seasonal pattern of epifauna abundance in New Jersey was similar to that in Virginia with greatest values found in the fall and lowest values in the summer (Table 4).

\section{Epifaunal Biomass}

Though they are likely an important food source for higher trophic levels, epifauna in these habitats have a standing stock biomass of a few tens of grams AFDW per $\mathrm{m}^{2}$. A more important measure of the importance of epifauna to the trophic structure in 
these habitats would be secondary production, which was not measured in this study. Few significant differences were observed among the biomass data. In Virginia, there were no significant effects of habitat type, season, or their interaction on epifaunal biomass. In New Jersey, epifauna biomass was lower in the summer than in fall or spring and no differences were observed between habitat type or its interaction with season (Table 4).

\section{Epifaunal Community Structure}

Nonmetric multidimensional scaling plots revealed differences in epifaunal community structure in Virginia across season and habitat type (Fig. 7A). Analysis of similarity confirmed these differences among seasons $(R=0.60$, significance level $=0.1 \%$ ) and among habitat types, with communities on clam nets quite dissimilar from those on uncultivated and harvested sites $(R=0.71$, significance level $=0.1 \%$, in both cases) and less dissimilarity between uncultivated and harvested
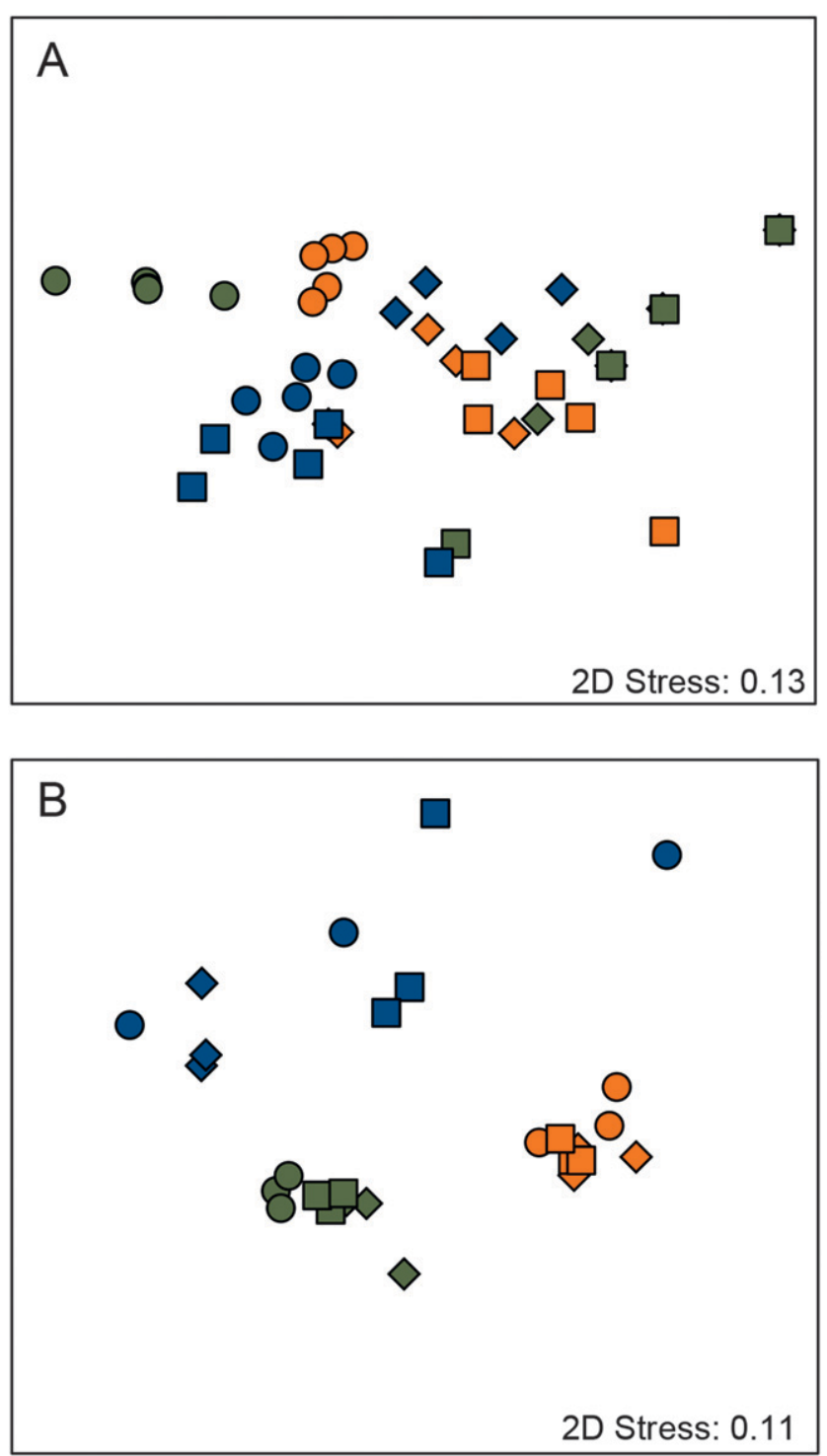

Figure 7. Two-dimensional nMSD plot of epifaunal community similarity based on square root transformed abundance data between habitat types by season in (A) Virginia and (B) New Jersey. Symbols as in Figure 4 sites $(R=0.37$, significance level $=0.1 \%)$. Similarity percentage analysis revealed that differences in epifaunal community structure on clam nets and those in uncultivated and harvest sites were primarily driven by high abundances of the decapods Hippolyte pleuracantha and, to a lesser extent, Crangon septemspinosa, and amphithoid amphipods associated with clam nets, and by the presence of the eastern mud snail Tritia obsoleta in the uncultivated and harvested sites.

For the New Jersey data, nMDS plots (Fig. 7B) and ANOSIM revealed strong differences in epifaunal community structure among all seasons $(R$ statistics ranging from 0.82 to 1.0 , significance levels $=0.1 \%-0.3 \%)$ and between communities associated with clam nets and those found in uncultivated $(R=$ 0.63 , significance level $=0.4 \%)$ and harvested sites $(R=0.66$, significance level $=0.2 \%)$. Similarity percentage analysis revealed that differences in community structure among habitat types were primarily driven by high abundances of the amphipods (Ampelisca spp.) and mysid shrimp (Neomysis americana) at uncultivated and harvested sites relative to the cultivated sites, and to the threeline mud snail (Tritia trivata) that was found in greater abundance in cultivated sites than the others.

\section{Macroalgal Biomass}

In Virginia, there was a clear pattern of variation in macroalgal biomass across habitat type (Fig. 8A). Macroalgae generally forms dense, though somewhat patchy, mats on the predator exclusion nets on clam farms throughout Virginia from early April through early November (Luckenbach, personal observation). Clam nets maintained algal mats throughout this study (April-October). Raw and transformed data on macroalgal biomass from Virginia failed to meet the assumptions of ANOVA, so separate nonparametric Kruskal-Wallis tests were run for effects of habitat type and season. Habitat type had a significant effect on algal biomass, with clam culture areas having higher biomass than either harvested or uncultivated areas. There was no significant effect of season (Table 4).

Two-way ANOVA on the data from New Jersey revealed a significant interaction between the main effects, so the data were parsed and separate one-way ANOVA were run for the effects of habitat type within each season and the effects of season within each habitat type (Table 4). A Kruskal-Wallis test indicated a significant effect of habitat type during the spring (Table 4), although a Tukey's test was unable to detect significant differences in pairwise comparisons between these habitats, it is clear that greater macroalgal biomass in the samples from the clam nets are responsible for this effect (Fig. 8B). No significant effects of habitat type were observed during any other season (Table 4). A significant effect of season on macroalgal biomass in the New Jersey samples was observed only within the harvested areas, where the fall had greater values than the spring and summer (Table 4).

\section{Macroalgal Species Richness}

A total of 10 macroalgal taxa were collected throughout the course of the study (Appendix, Table A1). The mean number of species collected in a single sample generally ranged between one and four (Fig. 8C, D). No significant effects of season or habitat type on macroalgal species richness were observed (Table 4). During the spring and summer, macroalgal species richness was greatest in the clam culture areas, but this pattern 

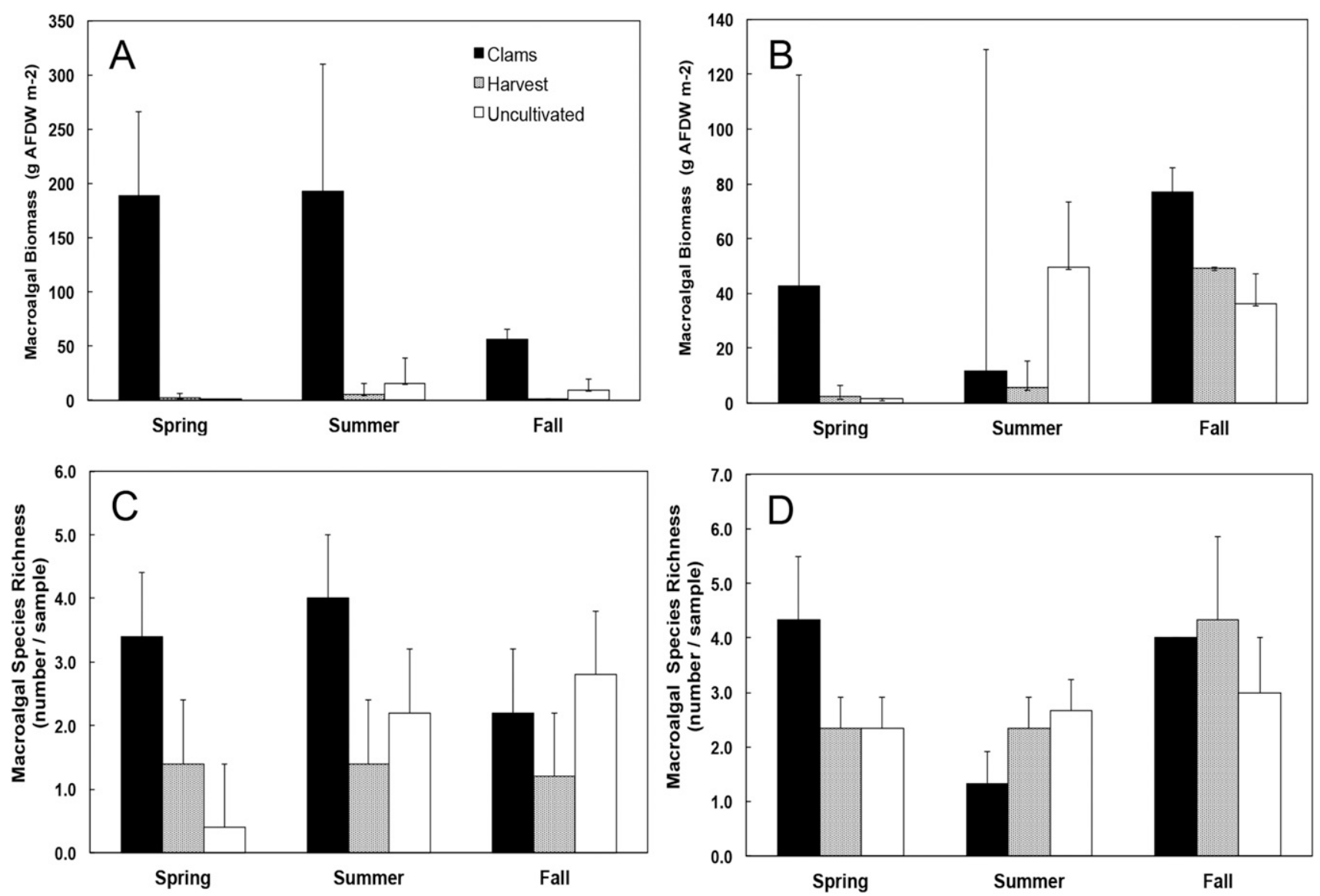

Figure 8. Mean macroalgal biomass in (A) Virginia and (B) New Jersey, and species richness (C) Virginia and (D) New Jersey by season and habitat type in suction samples. Note the scale difference. Labels and error bars as in Figure 3.

was not seen in the fall when there were no differences in macroalgal species richness between habitat types (Table 4). Significant, but different, effects of season were observed in the clam culture areas and the uncultivated areas, with the former having greatest species richness in the spring and the latter in the fall (Table 4).

Two-way ANOVA on the New Jersey data also revealed a significant interaction between habitat type and season on macroalgal species richness, so separate one-way tests were run. No significant effects of habitat type on macroalgal species richness were observed during any of the seasons in these analyses. Within the clam culture area, there was a significant effect of season, with spring having the highest richness and summer having the lowest (Table 4).

\section{Benthic Cores}

\section{Species Richness}

Infaunal communities were dominated by polychaetes, amphipods, and molluscs, with some obvious differences between sites and habitat types (Table 5).

When cultured clams were included in the analysis (Table 5), they were the dominant component of the infaunal community under nets with older clams. They constitute a smaller proportion of the infaunal community with younger ( $0-1$ y class) clams, and in harvested areas and between the rows on clam farms. In Virginia, areas not under clam nets were numerically dominated by the cellophane tubeworm Spiochaetopterus costarum oculatus (Webster, 1879), whereas in New Jersey ampeliscid amphipods (Ampelisca spp.) dominated these habitats.

Mean species richness by site and habitat ranged from 1.3 in harvested areas in New Jersey to 3.8 at the uncultivated areas in Virginia, but there were high variances in these estimates because of the patchy distribution of species (Fig. 9A, B). Both raw and transformed data from Virginia failed to meet the assumption of normality, so a Kruskal-Wallis test was conducted for the effects of habitat type on infaunal macrobenthic species diversity. This test revealed a significant effect of habitat type (Table 5). Pairwise multiple comparison tests revealed that uncultivated areas and areas under clam nets did not differ from one another in species richness and that both had significantly higher species richness than the rows between clam beds and harvested areas (Fig. 9A). For the New Jersey data, one-way ANOVA failed to detect a significant difference in species richness between habitat types (Table 5).

When cultured clams were included in the analyses of Virginia data, species richness in the uncultivated and clam areas were comparable and generally higher than in other habitats (Table 5). In New Jersey, no effects of habitat type on species richness were observed when cultured clams were either included or excluded from the analyses (Table 5).

\section{Macrofaunal Abundance}

Mean macrofaunal abundance was lowest in the recently harvested areas and greatest in the uncultivated areas, ranging 
TABLE 5.

Summary of statistical analysis of infaunal data in VA and NJ in three seasons in three habitats.

\begin{tabular}{lcc}
\hline \hline Dependent variable (core) & Habitat & Post hoc summary \\
\hline \multicolumn{2}{c}{ Species richness (excluding clams) } & \\
VA* & $<0.001$ & $\mathrm{Uc}>\mathrm{B}, \mathrm{Uc}=\mathrm{H}=\mathrm{C}, \mathrm{C}>\mathrm{B}$ \\
NJ & 0.097 & \\
Species richness (including clams) & \\
VA* & $<0.001$ & $\mathrm{Uc}=\mathrm{C}, \mathrm{Uc}=\mathrm{H}$, \\
& & $\mathrm{Uc}>\mathrm{B}, \mathrm{H}=\mathrm{B}$ \\
NJ & 0.436 & \\
Abundance (excluding clams) & $<0.001$ & $\mathrm{Uc}>\mathrm{C}>\mathrm{B}, \mathrm{C}=\mathrm{H}, \mathrm{H}=\mathrm{B}$ \\
VA & 0.025 & $\mathrm{Uc}>\mathrm{H}$, all others ND \\
NJ & $>0.001$ & $\mathrm{Uc}=\mathrm{C}>\mathrm{B}=\mathrm{H}$ \\
Abundance (including clams) & \\
VA & 0.063 & \\
NJ & $<0.001$ & $\mathrm{C}=\mathrm{Uc}>\mathrm{B}, \mathrm{C}>\mathrm{H}$, \\
Biomass (excluding clams) & $\mathrm{Uc}=\mathrm{H}, \mathrm{B}=\mathrm{H}$ \\
VA & 0.011 & $\mathrm{C}>\mathrm{H}$, all others ND \\
NJ & $<0.001$ & $\mathrm{C}>\mathrm{Uc}>\mathrm{B}, \mathrm{C}>\mathrm{H}$, \\
Biomass (including clams) & $\mathrm{Uc}=\mathrm{H}, \mathrm{B}=\mathrm{H}$ \\
VA & $<0.001$ & $\mathrm{C}>\mathrm{H}=\mathrm{Uc}, \mathrm{C}=\mathrm{Yc}$, \\
NJ & & $\mathrm{Yc}=\mathrm{Uc}$ \\
\hline
\end{tabular}

Sp, spring; Su, summer; F, fall; C, clam plot; H, harvested plot; Uc, uncultivated area; VA, Virginia; NJ, New Jersey; B, between rows; Yc = young clam plot. Values are $P$ values from one-way ANOVA and Kruskal-Wallis tests as indicated below. Inequalities in the post hoc tests indicate $P$ values $\leq 0.05$.

* VA ANOVA normality assumptions not met, Kruskal-Wallis test.

from 361 to over 3,500 individuals $/ \mathrm{m}^{2}$ in Virginia (Fig. 9C) and from 148 to nearly 8,000 individuals $/ \mathrm{m}^{2}$ in New Jersey (Fig. 9D). The high number in New Jersey was due exclusively to ampeliscid amphipods. In Virginia, when cultured clams are included in the analysis, macrofaunal abundance varied significantly across habitat type, with the uncultivated areas having greater abundance of macrobenthic infauna than the other habitat types (Table 5). When cultured clams are excluded from the analysis, infaunal abundance in the uncultivated areas in Virginia was significantly greater than in other areas (Table 5). In New Jersey, no differences were observed when cultured clams were included in the analyses and uncultivated areas were greater than harvest areas when clams were excluded (Table 5).

\section{Macrofaunal Biomass}

Biomass of macrobenthic infauna in Virginia followed a slightly different pattern than abundance. When cultured clams were included in the analysis of data from Virginia, there was a significant effect of habitat type with clam beds having significantly greater biomass than the other areas (Table 5). When cultured clams were excluded from the analysis, uncultivated areas and areas under the clam nets had similar infaunal biomass, and both of these had significantly greater biomass than the harvested areas. The rows and harvested areas were not different from each other and had the lowest biomass (Table 5). In New Jersey, when cultured clams are included in the analysis, clam beds with old clams ( $>1$ y old) and ones with young clams $(<1$ y old $)$ had comparable biomass and were generally greater than other habitats (Table 5). When cultured clams were excluded from the analyses, only the areas with old clams and recently harvested areas had significantly different total infaunal biomass (Table 5). Variability was extremely high between replicate samples and analyses based on ranked data (Table 5) overlook much of this variability.

\section{Macrofaunal Community Structure}

Nonmetric multidimensional scaling plots (not shown) and ANOSIM revealed a high degree of dissimilarity in infaunal macrobenthos community structure in Virginia between uncultivated sites and under clam nets $(R=1.0$, significance level $=$ $10 \%)$ and between uncultivated and harvested sites $(R=0.93$, significance level $=10 \%$ ), and a lesser degree between harvested sites and under clam nets $(R=0.52$, significance level $=10 \%)$. The remaining comparisons of each site with the community between the rows in clam farm revealed higher similarity between groups ( $R \leq 0.26$, significant level $\geq 20 \%$ ). Similarity percentage analysis revealed that the observed differences in infaunal community structure in Virginia were associated with the polychaete Spiochaetopterus costarum oculatus that occurred in high abundance in the uncultivated sites, low abundance in harvested sites, and was absent under clam nets.

For the New Jersey data, nMDS plots (not shown) and ANOSIM revealed a high degree of dissimilarity between most sites tested, with uncultivated sites-old clam beds comparisons and old clam beds-young clam beds comparisons both having $R=1$, significance levels $=10 \%$ and the remaining comparisons with $R$ statistics between 0.7 and 0.85 , significance levels $=10 \%$; the only exception being uncultivated sites and young clam beds, which had a high degree of similarity $(R=0.22$, significance level $=30 \%)$. Similarity percentage analyses revealed that dissimilarity between infaunal communities in old clam beds and uncultivated sites, and young clam beds and harvested sites was largely the result of the greater abundances of orbinid and lumbrinerid polychaetes in the old clam sites and a greater abundance of Ampelisca sp. in the three latter sites.

\section{DISCUSSION}

The distribution, abundance, biomass, species richness, and community composition of nektonic, demersal, epibenthic, and infaunal organisms in cultivated and uncultivated shallow-water habitats in Virginia and New Jersey were examined in an effort to better understand the effects of intensive clam culture on estuarine communities. Using multiple gear types and sampling over several consecutive days in each of three seasons yielded a robust dataset for examining patterns of species occurrence in clam farms - including over, on, and under predator exclusions nets, in recently harvested areas within the farms, on nearby uncultivated bottom habitats, and between the rows of nets. Although clear differences in some response variables were observed among seasons, the most striking result was the small number of significant differences observed among habitat types. Of 39 response variables tested (21 in New Jersey and 18 in Virginia), the mean values associated with cultured clams (i.e., above, on, or under the clam nets) in 26 instances did not differ significantly from uncultivated areas during any of the seasonal samples, 4 had decreased values compared with uncultivated areas, and 8 had increased values relative to uncultivated areas 

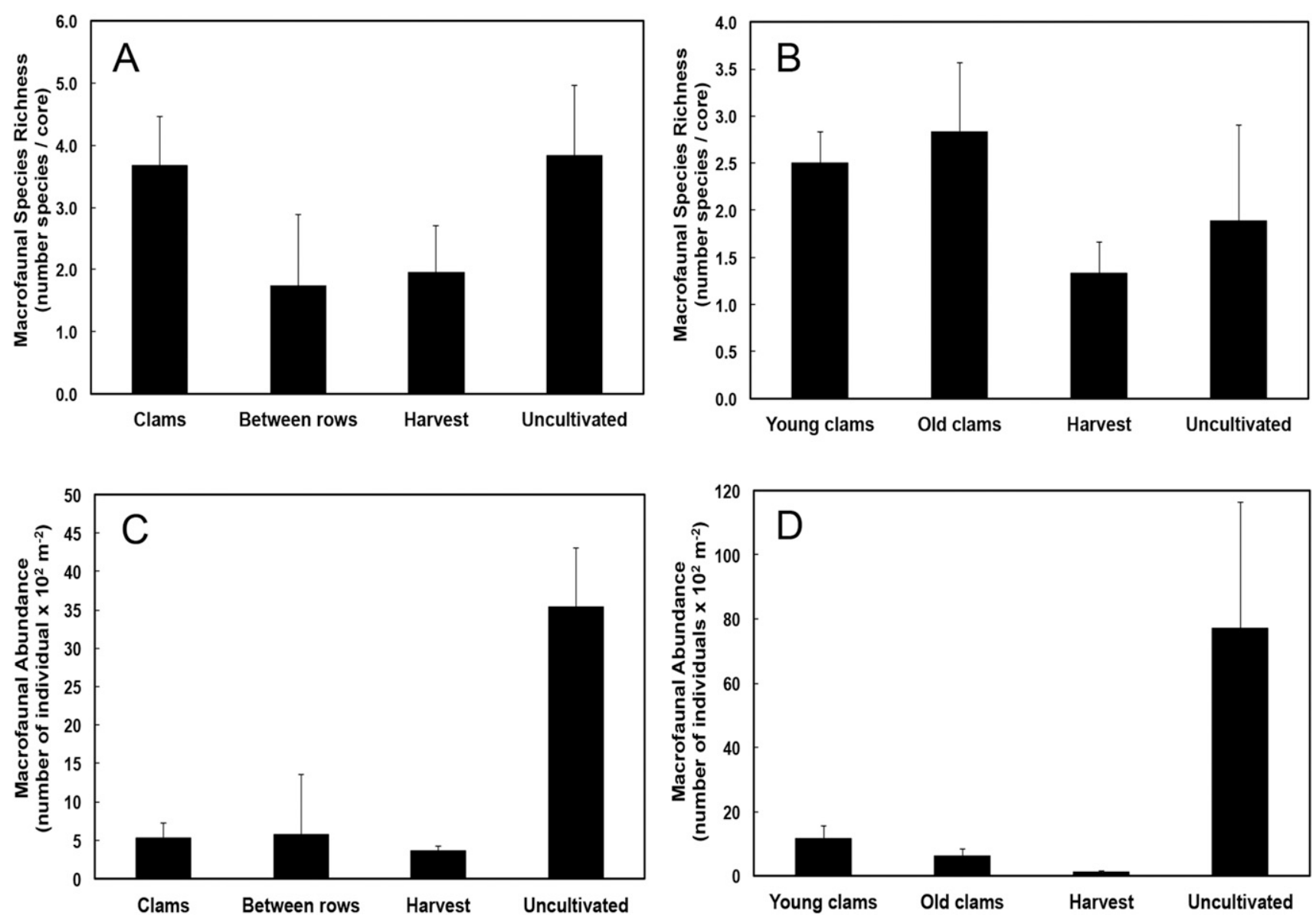

Figure 9. Mean macrofaunal species richness (inclusive of cultured clams) in (A) Virginia and (B) New Jersey, and abundance (exclusive of clams) in (C) VA and (D) NJ by habitat. Error bars represent 1 SD above the mean. Note the scale difference.

during at least one season (Table 6). For harvested areas, 5 of the 39 response variables showed significant decreases relative to uncultivated areas during at least one season, with 33 having no significant differences throughout the study and one response, blue crab biomass, increasing in harvested areas relative to uncultivated areas (Table 6).

Failure to reject the null hypothesis of no difference between clam culture sites and uncultivated areas for many of the biotic variables investigated raises the concern that this may be a reflection of low statistical power in the study. Lacking the required a priori variance estimates needed to make reasonable power estimates before initiating the study and recognizing that post hoc power estimation has been shown to be of limited value (Hoenig \& Heisey 2001, Levine \& Ensom 2001), confidence intervals were used as recommended by these authors and others to provide some evaluation of the adequacy of the sample size. In short, this method involves using the data to compute a $95 \%$ confidence interval around observed difference estimates for the variable of interest between treatment levels (e. g., epifaunal species richness in the summer suction samples from clam nets and uncultivated areas in New Jersey). If the confidence interval spans zero, the interpretation based on the available data is that the true difference between the parameters could include the null. These analyses were run for all of the parameter comparisons summarized in Table 6 with the result that in less than $10 \%$ of the cases in which there was a failure to reject the null did the confidence intervals fail to include the zero and in no instance was this observed in all seasons for any set of comparable difference estimates. This finding does not provide a true estimate of power, but does indicate that in more than $90 \%$ of the cases in which the null hypothesis was not rejected, the data collected provide high confidence that the null assertion of no difference could occur.

Significant seasonal effects were observed in all of the response variables except two, epifaunal biomass and macroalgal biomass, both in Virginia (Table 4). Had sampling extended later into the fall or winter, when macroalgal cover on the nets is much lower (Luckenbach, personal observation), season would have become significant for both of these variables. This seasonal variation is expected, but it does indicate that the sampling design was sufficiently robust to identify these differences.

The most abundant species caught in the fyke and seine nets (silver perch, American eels, spot, Atlantic silversides, pigfish, black sea bass, and mature blue crabs) are those that move freely among the habitats that we sampled. The decreased fish abundance in fyke net samples in Virginia over cultivated and harvested habitats relative to uncultivated areas (Table 6) was observed only during summer samples (Fig. 4, Table 2) and was the result of capturing more silver perch at the uncultivated site. Though silver perch were collected in fyke net samples within the clam farms in both New Jersey and Virginia, it is possible that they have some preference for uncultivated areas; alternatively, 
TABLE 6.

Summary of the effects of habitat type on fauna and flora at the Virginia and New Jersey sites.

\begin{tabular}{|c|c|c|c|c|c|}
\hline \multirow[b]{2}{*}{ Response variable } & \multicolumn{2}{|c|}{$\begin{array}{c}\text { Clam } \\
\text { beds }\end{array}$} & \multicolumn{2}{|c|}{ Harvested } & \multirow{2}{*}{$\begin{array}{c}\begin{array}{c}\text { Between } \\
\text { rows }\end{array} \\
\text { VA }\end{array}$} \\
\hline & VA & $\mathbf{N J}$ & VA & NJ & \\
\hline \multicolumn{6}{|l|}{ Nekton and Demersal Fauna } \\
\hline \multicolumn{6}{|l|}{ Fyke net samples } \\
\hline Species richness & - & - & - & - & \\
\hline Fish abundance & $\downarrow$ & - & $\downarrow$ & - & \\
\hline Fish length & - & - & - & - & \\
\hline Fish biomass & & - & & - & \\
\hline Crustacean abundance & - & - & - & - & \\
\hline Blue crab biomass & & - & & $\uparrow$ & \\
\hline Terrapin abundance & & - & & & \\
\hline \multicolumn{6}{|l|}{ Seine samples } \\
\hline Species richness & - & - & - & - & \\
\hline Fish abundance & - & - & - & - & \\
\hline Crustacean abundance & $\uparrow$ & - & - & - & \\
\hline \multicolumn{6}{|l|}{ Epifauna and Infauna } \\
\hline \multicolumn{6}{|l|}{ Suction samples } \\
\hline Epifaunal abundance & $\uparrow$ & $\downarrow$ & - & - & \\
\hline Epifaunal biomass & - & - & - & - & \\
\hline Epifaunal species richness & $\uparrow$ & - & - & - & \\
\hline \multicolumn{6}{|l|}{ Benthic cores } \\
\hline $\begin{array}{l}\text { Infaunal species richness } \\
\text { (inclusive of clams) }\end{array}$ & - & - & - & - & $\downarrow$ \\
\hline $\begin{array}{l}\text { Infaunal species richness } \\
\text { (exclusive of clams) }\end{array}$ & - & - & - & - & $\downarrow$ \\
\hline $\begin{array}{l}\text { Infaunal abundance } \\
\quad \text { (inclusive of clams) }\end{array}$ & - & - & $\downarrow$ & - & - \\
\hline $\begin{array}{l}\text { Infaunal abundance } \\
\text { (exclusive of clams) }\end{array}$ & $\downarrow$ & $\downarrow$ & $\downarrow$ & $\downarrow$ & $\downarrow$ \\
\hline $\begin{array}{l}\text { Infaunal biomass } \\
\text { (inclusive of clams) }\end{array}$ & $\uparrow$ & $\uparrow$ & - & - & $\downarrow$ \\
\hline $\begin{array}{l}\text { Infaunal biomass } \\
\text { (exclusive of clams) }\end{array}$ & - & - & $\downarrow$ & - & $\downarrow$ \\
\hline \multicolumn{6}{|l|}{ Macroalgae } \\
\hline Macroalgae biomass & $\uparrow$ & $\uparrow$ & - & - & \\
\hline Macroalgae species richness & $\uparrow$ & - & - & - & \\
\hline
\end{tabular}

Effects are indicated relative to uncultivated areas as follows: -, not different; $\downarrow$, decreased relative to uncultivated areas; $\uparrow$, increased relative to uncultivated areas. Blanks indicate that no comparisons were made.

the difference observed in Virginia may simply be a result of the schooling behavior of these fish and the chance collection of a few schools. Other less common fish, such as the naked goby Gobiosoma bosci (Lacepède, 1800), the lined seahorse Hippocampus erectus (Perry, 1810), and northern pipefish Syngnathus fuscus (Storer, 1839), showed a greater affinity for the clam beds in response to the structure provided by the attached macroalgae.

Among epifauna, there was a clear shift, at least in Virginia, from a community dominated by mud snails and tube-building amphipods in uncultivated areas to a more diverse community with numerous errant amphipods (e.g., Gammaridae and Ampithoidae) and gastropods that graze on macroalgae and other epiphytes in the cultivated areas. Total epifauna abundance on clam nets in Virginia exceeded that in uncultivated areas in two out of three seasons (Fig. 6C, Table 4). Similar patterns were not observed in New Jersey (Fig. 6D, Table 4), likely reflecting the more equitable distribution of macroalgae across habitats discussed below.

Infaunal macrobenthos demonstrated the most significant responses in abundance and biomass to cultivation, likely as a result of physical disturbance associated with planting and harvesting as reported by Kaiser et al. (1998) and Spencer et al. (1998), but also possibly due to bioturbation and competitive exclusion by the clam. Of course, when the cultured clams are included in these calculations, particularly for biomass, the pattern is reversed and clam sites have greater or equal values. In samples from the fall, infaunal biomass, inclusive of Mercenaria, was greater under the clam nets relative to uncultivated areas (Virginia: $381 \mathrm{~g} / \mathrm{m}^{2}$ under nets, $15 \mathrm{~g} / \mathrm{m}^{2}$ in uncultivated areas; New Jersey: $287 \mathrm{~g} / \mathrm{m}^{2}$ under nets with $>1$-y-old clams, $51 \mathrm{~g} / \mathrm{m}^{2}$ in uncultivated areas).

There are several important differences between the sites and culture practices in Virginia and New Jersey, which may have contributed to differences we observed in abundance of epibenthic and infaunal organisms. First, the New Jersey site is in a coastal bay system with extensive Spartina marsh and a tidal range greater than $1 \mathrm{~m}$. High turbidity, coupled with the subtidal depth of the clam beds throughout much of the tidal cycle, likely results in light limitation for macroalgal growth. As a result, the macroalgal biomass in New Jersey only exceeded 50 g AFDW/ $\mathrm{m}^{2}$ once during the fall sampling period (Fig. 8D). Macroalgae was also distributed across habitat types with moderate abundances in harvested and uncultivated areas. In contrast, the Virginia site is a tidally dominated tributary of the Chesapeake Bay with only small fringing marshes, excellent water clarity, and a tidal amplitude of less than $1 \mathrm{~m}$. As a result, dense macroalgae mats develop on top of the nets from spring through fall, reaching nearly $200 \mathrm{~g} \mathrm{AFDW} / \mathrm{m}^{2}$ in the spring and summer (Fig. 8C). These mats are often so dense that they obstruct flow to the clams and the culturists find it necessary to sweep the nets clean. In New Jersey, the nets are less often swept to remove macroalgae, but they are swept to remove Ampelisca spp. and their tubes. Only small amounts of macroalgae were found in uncultivated and harvested areas in Virginia, whereas in New Jersey, a large component of the macroalgal community is composed of an unattached drifting assemblage (Kraeuter, personal observation) that moves throughout the area. Additionally, the clam farms in this study differed in scale. In New Jersey, sampling was conducted on a farm with approximately 100 beds measuring $4.2 \mathrm{~m} \times 5.1 \mathrm{~m}$. The scale of the clam farm in Virginia was much larger, with over 1,000 beds measuring $4 \mathrm{~m} \times 17 \mathrm{~m}$. The combination of these factors makes the benthic habitat on the Virginia farm more distinctly different from uncultivated areas, than is the case in New Jersey. Specifically, the benthic macrofauna in the Virginia farm is much more dominated by epifauna compared with infauna in uncultivated areas; a pattern that not as evident in New Jersey.

Numerous studies have examined the utilization by fishes and invertebrates of structured habitats such as seagrass meadows and oyster reefs in intertidal and shallow subtidal estuarine environments (e.g., Heck et al. 2003, Bostrom et al. 2006, Hosack et al. 2006, Horinouchi 2007) and generally found differences in community structure compared with unstructured environments, including elevated abundances and species richness. The effects of structure associated with shellfish aquaculture are less well studied (but see McDonald et al. 2015, VanBlaricom et al. 2015). In the only similar study with Mercenaria mercenaria, Powers et al. (2007) examined the 
utilization of macroalgal and other epibiota associated with clam culture sites in North Carolina by motile invertebrates and juvenile fishes in comparison with seagrass [Zostera marina (Linnaeus, 1753) and Halodule wrightii (Ascherson, 1868)] and barren sandflat habitats. They found that the macroalgae/ epifaunal mats had similar biomass to that of natural seagrass habitats, and that both structured habitats supported elevated abundances of motile invertebrates and juvenile fishes relative to the unstructured sandflat. Although elevated abundances of epifauna associated with macroalgal mats on clam beds relative to uncultivated sites were observed in Virginia in the present study, similar patterns were not observed for fish abundance or epifaunal abundance in New Jersey (Table 6). These differences between findings of the present study and that of Powers et al. (2007) were attributed to several factors. First, the netting on their experimental plots was not cleaned during the 21-mo duration of their sampling; whereas in Virginia, the nets on the commercial clam farm were periodically cleaned by the farmer to reduce obstruction of flow. As previously noted in New Jersey, macroalgae was sparser than in Virginia (and North Carolina) and distributed across the habitat types. Second, Powers et al. targeted primarily juvenile fishes and motile crustaceans with their seine samples, whereas this study used fyke net arrays targeting adult fishes, suction sampling of epibenthos, and core sampling of infaunal macrobenthos. Other uncharacterized habitat differences may have also played a role. Although the present study found four cases of negative responses (i.e., the response variable lower above, on, or in clam beds relative uncultivated sites), similar to Powers et al. it found positive responses in eight of other response variables (Table 6).

In a series of publications, Spencer et al. (1996, 1997, 1998) examined the effects of cultivation of Manila clams from the early seeding stage through harvest on infaunal macrobenthos and found that some species increased in abundance, whereas others declined in clam beds relative to control sites and that recovery following harvest was generally rapid. Of 30 tests among infauna, the present study observed negative responses (clam beds or harvested areas or between rows less than uncultivated sites) in 11 , and only 3 negative and 7 positive effects on fishes, epifauna, and macroalgae (Table 6). Recent studies by VanBlaricom et al. (2015) and McDonald et al. (2015) focused on the harvest and culture phases of geoduck Panopea generosa, respectively, on intertidal beaches in Washington State. They observed strong seasonal effects on infaunal and epifaunal macrobenthic community structure, but little to no effect associated with the clam culture. With the exception of a few groups like flatfish, fishes and motile macroinvertebrates had greater abundances at culture sites relative to uncultivated reference sites (McDonald et al. 2015). Though culture techniques differ substantially between Manila clams, geoduck, and hard clam aquaculture, modest impacts to most infaunal, epifaunal, demersal, and nektonic species are consistent across these studies.

Though this study does not provide data on habitat-specific trophic linkages, it suggests that the reduced availability of infaunal prey for higher trophic levels (both as a result of predator exclusion nets and reduced abundances) on clam farms is offset by an increase in epibenthic prey for demersal feeding fishes and crustaceans. Future research should quantify the trophic linkages and energy transfer between trophic levels on and around clam farms. In the meantime, these findings suggest that utilization of clam farms by estuarine fish and crustacean assemblages is comparable to that of uncultivated areas.

\section{ACKNOWLEDGMENTS}

We thank George Mathis of Mathis Clam Farm and Mike Pierson and Jeff Conrow of Cherrystone Aquafarms, Inc. for their assistance and for allowing us to conduct this research on their clam farms. We are grateful to Alan Birch, P. G. Ross, Sean Fate, and Edward Smith for assistance in the collection and processing of samples in Virginia. In New Jersey, George Mathis, Emily Scarpa, Susan Bradbury, Emma Green-Beach, Iris Burt, Kurt Cheng, and Jenny Paterno assisted with the fieldwork, sorting and measuring samples. Lisa Kellogg and Jennifer Dryer assisted with statistical analyses. This work was supported by a grant from NOAA to the East Coast Shellfish Research Institute. Contribution 3593 from the Virginia Institute of Marine Science.

\section{LITERATURE CITED}

Anderson, G. J. \& K. K. Chew. 1980. Intertidal culture of the Manila clam Tapes japonica using hatchery-reared seed clams and protective net enclosures. J. Shellfish Res. 1:131.

Anderson, G. J. 1982. Intertidal culture of the Manila clam, Tapes philippinarum, using large netting enclosures in Puget Sound, Washington. MSc. thesis, University of Washington, Seattle. 100 pp.

Anderson, G. J., M. B. Miller \& K. K. Chew. 1982. A guide to Manila clam aquaculture in Puget Sound. Seattle, WA: Washington Sea Grant Technical Report, WSG 82-4, University of Washington. 45 pp.

Bartoli, M., D. Nizzoli, P. Vidroli, E. Turolla, G. Castaldelli, E. A. Fano \& R. Rossi. 2001. Impact of Tapes philippinarum farming on nutrient dynamics and benthic respiration in the Sacca di Goro. Hydrobiolologia. 455:203-212.

Bostrom, C., E. L. Jackson \& C. A. Simenstad. 2006. Seagrass landscapes and their effects on associated fauna: a review. Estuar. Coast. Shelf Sci. 68:383-403.

Castagna, M. 1970. Field experiments testing the use of aggregate covers to protect juvenile clams. Proc. Natl. Shellfish. Assoc. 60:2.

Castagna, M. \& J. N. Kraeuter. 1977. Mercenaria culture using stone aggregate for predator protection. Proc. Natl. Shellfish. Assoc. 67:1-6.
Coen, L. D., B. R. Dumbauld \& M. L. Judge. 2011. Chapter 9, Expanding shellfish aquaculture: a review of the ecological services provided by and impacts of native and cultured bivalves in shellfishdominated ecosystems. In: Shumway, S. E., editor. Shellfish aquaculture and the environment. Chichester, England: John Wiley and Sons. pp. 239-295.

Dumbauld, B. R., J. L. Ruesink \& S. S. Rumrill. 2009. The ecological role of bivalve shellfish aquaculture in the estuarine environment: a review with application to oyster and clam culture in West Coast (USA) estuaries. Aquaculture 290:196-223.

Glock, J. W. \& K. K. Chew. 1979. Growth, recovery and movement of Manila clams, Venerupis japonica (Deshayes) at Squaxin Island, Washington. Proc. Natl. Shellfish. Assoc. 69:15-20.

Goulletquer, P., R. Robert \& G. Trut. 1999. Manila clam Tapes philippinarum culture: sediment-clam interactions. Aquat. Living Resour. 12:45-56.

Heck, K. L., G. Hays \& R. J. Orth. 2003. Critical evaluation of the nursery role hypothesis for seagrass meadows. Mar. Ecol. Prog. Ser. 253:123-136.

Hoenig, J. M. \& D. M. Heisey. 2001. The abuse of power: the pervasive fallacy of power calculations for data analysis. Am. Stat. 55:19-24. 
Horinouchi, M. 2007. Review of the effects of within-patch scale structural complexity on seagrass fishes. J. Exp. Mar. Biol. Ecol. 350:111-129.

Hosack, G. R., D. R. Dumbauld, J. L. Ruesink \& D. A. Armstrong. 2006. Habitat associations of estuarine species: cof intertidal mudflat, seagrass (Zostera marina), and oyster (Crassostrea gigas) habitats. Estuaries and Coasts 29:1150-1160.

Jie, H., Z. Zhinan, Y. Zishan \& J. Widdows. 2001. Differences in the benthic-pelagic particle flux (biodeposition and sediment erosion) at intertidal sites with and without clam (Ruditapes philippinarum) cultivation in eastern China. J. Exp. Mar. Biol. Ecol. 261:245-261.

Kaiser, M. J., D. B. Edwards \& B. E. Spencer. 1996. A study of the effects of commercial clam cultivation and harvesting on benthic infauna. Aquat. Living Resour. 9:57-63.

Kaiser, M. J., I. Laing, S. D. Utting \& G. M. Burnell. 1998. Environmental impacts of bivalve mariculture. J. Shellfish Res. 17:59-66.

Kraeuter, J. N. \& M. Castagna. 1977. An analysis of gravel, pens, crab traps and current baffles as protection for juvenile hard clams, Mercenaria mercenaria. J. World Aquacult. Soc. 8:581-592.

Kraeuter, J. N. \& M. Castagna. 1980. Effects of large predators on the field culture of the hard clam, Mercenaria mercenaria. Fish Bull. 78:538-541.

Kraeuter, J. N. \& M. Castagna. 1985a. The effects of seed size, shell bags, crab traps, and netting on the survival of the northern hard clam Mercenaria mercenaria (Linne). J. Shellfish Res. 5:69-72.

Kraeuter, J. N. \& M. Castagna. 1985b. The effect of clam size, net size, and poisoned bait treatments on survival of hard clam, Mercenaria mercenaria, seed in field plots. J. World. Aquacult. Soc. 16:337-385.

Kraeuter, J. N. \& M. Castagna. 1989. Chapter 6, Factors affecting the growth and survival of clam seed planted in the natural environment. In: Manzi, J. J. \& M. Castagna, editors. Clam mariculture in North America: developments in aquaculture and fisheries science, vol. 9. New York, NY: Elsevier. pp. 149-165.

Levine, M. \& M. H. Ensom. 2001. Post hoc power analysis: an idea whose time has passed? Pharmacotherapy 21:405-409.

McDonald, P. S., A. W. E. Galloway, K. C. McPeek \& G. R. VanBlaricom. 2015. Effects of geoduck (Panope generosa Gould, 1850 ) aquaculture gear on resident and transient macrofauna communities of Puget Sound, Washington. J. Shellfish Res. 34:189-202.

Menzel, R. W. \& H. W. Sims. 1964. Experimental farming of hard clams, Mercenaria mercenaria, in Florida. Proc. Natl. Shellfish. Assoc. 53:103-109.

Menzel, R. W., E. W. Cake, M. L. Haines, R. E. Martin \& L. A. Olsen. 1975. Clam mariculture in northwest Florida: field study on predation. Proc. Natl. Shellfish. Assoc. 65:59-62.

Miller, M. B., K. K. Chew, C. R. Jones, L. Godwin \& C. D. Magoon. 1978. Manila clam seeding as an approach to clam population enhancement. Seattle, WA: Washington Sea Grant WSG 78-2, University of Washington. $18 \mathrm{pp}$.

Mojica, R. \& W. G. Nelson. 1993. Environmental effects of a hard clam (Mercenaria mercenaria) aquaculture site in the Indian River Lagoon, Florida. Aquaculture 113:313-329.

Munroe, D. \& R. S. McKinley. 2007. Commercial Manila clam (Tapes philippinarum) culture in British Columbia, Canada: the effects of predator netting on intertidal sediment characteristics. Estuar. Coast. Shelf Sci. 72:319-328.
Murphy, A. E., I. C. Anderson \& M. W. Luckenbach. 2015. Enhanced nutrient regeneration at commercial hard clam (Mercenaria mercenaria) beds fuels macroalgal production. Mar. Ecol. Prog. Ser. 530:135-151.

National Agricultural Statistics Service. 2014. Census of aquaculture (2013), vol. 3, special studies, part 2. Washington, DC: National Agricultural Statistics Service. 98 pp.

Nizzoli, D., D. T. Welsh, E. A. Fano \& P. Viaroli. 2006. Impact of clam and mussel farming on benthic metabolism and nitrogen cycling, with emphasis on nitrate reduction pathways. Mar. Ecol. Prog. Ser. 315:151-165.

Nizzoli, D., D. T. Welsh \& P. Viaroli. 2011. Seasonal nitrogen and phosphorus dynamics during benthic clam and suspended mussel cultivation. Mar. Pollut. Bull. 62:1276-1287.

NRC. 2010. Ecosystem concepts for sustainable bivalve mariculture. Washington, DC: Committee for Best Practices for Shellfish Mariculture, National Research Council, National Academies Press. 179 pp.

Powers, M. J., C. H. Peterson, H. C. Summerson \& S. P. Powers. 2007. Macroalgal growth on bivalve aquaculture netting enhances nursery habitat for mobile invertebrates and juvenile fishes. Mar. Ecol. Prog. Ser. 339:109-122.

Spencer, B. E., D. B. Edwards \& P. F. Millican. 1991. Cultivation of Manila clams. Lowestoft, United Kingdom: Ministry of Agriculture, Fisheries and Food, Directorate of Fisheries Research. 29 pp.

Spencer, B. E., D. B. Edwards \& P. F. Millican. 1992. Protecting Manila clam (Tapes philippinarum) beds with plastic netting. Aquaculture 105:251-268.

Spencer, B. E., M. J. Kaiser \& D. B. Edwards. 1996. The effect of Manila clam cultivation on an intertidal benthic community: the early cultivation phase. Aquacult. Res. 27:261-276.

Spencer, B. E., M. J. Kaiser \& D. B. Edwards. 1997. Ecological effects of intertidal Manila clam cultivation: observations at the end of the cultivation phase. J. Appl. Ecol. 34:444-452.

Spencer, B. E., M. J. Kaiser \& D. B. Edwards. 1998. Intertidal clam harvesting: benthic community change and recovery. Aquacult. Res. 29:429-437.

Thompson, D. S. 1995. Substrate additive studies for the development of hardshell clam habitat in water of Puget Sound in Washington State: an analysis of effects on recruitment, growth, survival of the Manila clam, Tapes philippinarum, and on the species diversity and abundance of existing benthic organism. Estuaries 18:91-107.

Toba, D. R., D. S. Thompson, K. K. Chew, G. J. Anderson \& M. B. Miller. 1992. Guide to Manila clam culture in Washington. Seattle, WA: Washington Sea Grant Program, University of Washington. $80 \mathrm{pp}$.

VanBlaricom, G. R., J. L. Eccles, J. D. Olden \& P. S. McDonald. 2015. Ecological effects of the harvest phase of geoduck (Panope generosa Bould, 1850) aquaculture on infaunal communities in southern Puget Sound, Washington. J. Shellfish Res. 34:171-187.

Walne, P. R. 1974. Culture of bivalve molluscs. 50 years' experience at Conwy. Surrey, United Kingdom: Fishing News (Books Ltd.). 173 pp.

Whiteley, J. \& L. Bendell-Young. 2007. Ecological implications of intertidal mariculture: observed differences in bivalve community structure between farm and reference sites. J. Appl. Ecol. 44:495-505. 
Effects of Clam Aquaculture on Estuarine Biota

APPENDIX

TABLE A1.

Taxa collected in cultivated (clam beds and harvested) and uncultivated sites in virginia and new jersey.

\begin{tabular}{|c|c|c|c|c|c|c|c|}
\hline \multirow[b]{2}{*}{ Taxon } & \multirow[b]{2}{*}{ Common name } & \multicolumn{2}{|c|}{ Clam beds } & \multicolumn{2}{|c|}{ Harvested } & \multicolumn{2}{|c|}{ Uncultivated } \\
\hline & & VA & NJ & VA & NJ & VA & NJ \\
\hline \multicolumn{8}{|l|}{ Fishes } \\
\hline Dasyatis sabina & Atlantic stingray & & & & & $\mathrm{X}$ & \\
\hline Gobiosoma bosci & Naked goby & $\mathrm{X}$ & $\mathrm{X}$ & $\mathrm{X}$ & $\mathrm{X}$ & $\mathrm{X}$ & $\mathrm{X}$ \\
\hline Gobiesox strumosus & Skilletfish & $\mathrm{X}$ & & & & $\mathrm{X}$ & \\
\hline Strongylura marina & Atlantic needle fish & $\mathrm{X}$ & & $\mathrm{X}$ & & $\mathrm{X}$ & \\
\hline Brevoortia tyrannus & Menhaden & $\mathrm{X}$ & $\mathrm{X}$ & & & $\mathrm{X}$ & \\
\hline Alosa mediocris & Hickory shad & $\mathrm{X}$ & & & & & \\
\hline Menidia menidia & Atlantic silverside & $\mathrm{X}$ & $\mathrm{X}$ & $\mathrm{X}$ & $\mathrm{X}$ & $\mathrm{X}$ & $\mathrm{X}$ \\
\hline Anchoa mitchilli & Bay anchovy & $\mathrm{X}$ & & $\mathrm{X}$ & & $\mathrm{X}$ & $\mathrm{X}$ \\
\hline Syngnathus fuscus & Northern pipefish & $\mathrm{X}$ & $\mathrm{X}$ & $\mathrm{X}$ & & $\mathrm{X}$ & \\
\hline Fundulus majalis & Striped killifish & & & $\mathrm{X}$ & & & \\
\hline Fundulus heteroclitus & Mummichog & & $\mathrm{X}$ & $\mathrm{X}$ & $\mathrm{X}$ & & $\mathrm{X}$ \\
\hline Urophycis regia & Spotted hake & $\mathrm{X}$ & & & & & \\
\hline Perca flavescens & Yellow perch & $\mathrm{X}$ & & & & & \\
\hline Anguilla rostrata & American eel & $\mathrm{X}$ & $\mathrm{X}$ & $\mathrm{X}$ & $\mathrm{X}$ & $\mathrm{X}$ & $\mathrm{X}$ \\
\hline Paralichthys dentatus & Summer flounder & $\mathrm{X}$ & $\mathrm{X}$ & $\mathrm{X}$ & $\mathrm{X}$ & $\mathrm{X}$ & $\mathrm{X}$ \\
\hline Trinectes maculatus & Hogchoker & $\mathrm{X}$ & $\mathrm{X}$ & $\mathrm{X}$ & & $\mathrm{X}$ & $\mathrm{X}$ \\
\hline Symphurus plagiusa & Blackcheek tonguefish & & & $\mathrm{X}$ & & $\mathrm{X}$ & \\
\hline Hyporhamphus meeki & American halfbeak & & & $\mathrm{X}$ & & & \\
\hline Bairdiella chrysoura & Silver perch & $\mathrm{X}$ & $\mathrm{X}$ & $\mathrm{X}$ & $\mathrm{X}$ & $\mathrm{X}$ & $\mathrm{X}$ \\
\hline Tautoga onitis & Tautog & $\mathrm{X}$ & & $\mathrm{X}$ & $\mathrm{X}$ & & \\
\hline Leiostomus xanthurus & Spot & $\mathrm{X}$ & & $\mathrm{X}$ & & $\mathrm{X}$ & \\
\hline Hippocampus erectus & Lined seahorse & $\mathrm{X}$ & & $\mathrm{X}$ & & $\mathrm{X}$ & \\
\hline Cynoscion nebulosus & Speckled trout & $\mathrm{X}$ & & $\mathrm{X}$ & & $\mathrm{X}$ & \\
\hline Centropristis striata & Black sea bass & $\mathrm{X}$ & & $\mathrm{X}$ & & $\mathrm{X}$ & \\
\hline Cynoscion regalis & Gray trout (weakfish) & & & $\mathrm{X}$ & & $\mathrm{X}$ & \\
\hline Orthopristis chrysoptera & Pig fish & $\mathrm{X}$ & & $\mathrm{X}$ & & $\mathrm{X}$ & \\
\hline Chilomycterus schoepfi & Striped burrfish & & & & & $\mathrm{X}$ & \\
\hline Sphoeroides maculatus & Northern puffer & & & & & $\mathrm{X}$ & \\
\hline Micropogonias undulatus & Atlantic croaker & $\mathrm{X}$ & & $\mathrm{X}$ & & $\mathrm{X}$ & $\mathrm{X}$ \\
\hline Pomatomus saltatrix & Bluefish & & $\mathrm{X}$ & & $\mathrm{X}$ & $\mathrm{X}$ & $\mathrm{X}$ \\
\hline Chaetodipterus faber & Atlantic spadefish & & & $\mathrm{X}$ & & & \\
\hline Chasmodes bosquianus & Stripped blenny & $\mathrm{X}$ & & & & & \\
\hline Pogonias cromis & Black drum & $\mathrm{X}$ & & $\mathrm{X}$ & & $\mathrm{X}$ & \\
\hline Morone americanus & White perch & & & $\mathrm{X}$ & & & \\
\hline Opsanus tau & Oyster toadfish & $\mathrm{X}$ & & $\mathrm{X}$ & & $\mathrm{X}$ & \\
\hline Morone saxatilis & Stripped bass & $\mathrm{X}$ & & & $\mathrm{X}$ & & \\
\hline Selene vomer & Lookdown & & & & & $\mathrm{X}$ & $\mathrm{X}$ \\
\hline Apeletes quadracus & Fourspine stickleback & $\mathrm{X}$ & & & & & \\
\hline Hypsoblennius hentz & Feather blenny & $\mathrm{X}$ & & & & & \\
\hline Mugil cephalus & Flathead grey mullet & & & & & & $\mathrm{X}$ \\
\hline Menticirrhus saxatilis & Northern kingfish & & & & & & $\mathrm{X}$ \\
\hline Trachinotus falcatus & Permit & & & & & & $\mathrm{X}$ \\
\hline Ophidon margantum & Striped cusk-eel & & $\mathrm{X}$ & & $\mathrm{X}$ & & $\mathrm{X}$ \\
\hline Prionotus alatus & Spiny searobin & & & & & & $\mathrm{X}$ \\
\hline \multicolumn{8}{|l|}{ Reptiles } \\
\hline Malaclemys terrapin & Diamondback terrapin & & $\mathrm{X}$ & & $\mathrm{X}$ & & $\mathrm{X}$ \\
\hline \multicolumn{8}{|l|}{ Crustaceans } \\
\hline Palaemonetes vulgaris & Grass shrimp & $\mathrm{X}$ & $\mathrm{X}$ & $\mathrm{X}$ & $\mathrm{X}$ & $\mathrm{X}$ & $\mathrm{X}$ \\
\hline Palaemonetes intermedius & Grass shrimp & $\mathrm{X}$ & $\mathrm{X}$ & $\mathrm{X}$ & $\mathrm{X}$ & $\mathrm{X}$ & $\mathrm{X}$ \\
\hline Hippolyte pleuracantha & Broke-backed shrimp & $\mathrm{X}$ & & $\mathrm{X}$ & & $\mathrm{X}$ & \\
\hline Crangon septemspinosa & Sand shrimp & $\mathrm{X}$ & $\mathrm{X}$ & $\mathrm{X}$ & $\mathrm{X}$ & $\mathrm{X}$ & $\mathrm{X}$ \\
\hline Alpheus heterochaelis & Bigclaw snapping shrimp & $\mathrm{X}$ & & & & & \\
\hline Upogebia affinis & Coastal mud shrimp & $\mathrm{X}$ & & & & & \\
\hline Litopenaeus setiferus & White shrimp & $\mathrm{X}$ & & $\mathrm{X}$ & & $\mathrm{X}$ & \\
\hline Callinectes sapidus & Blue crab & $\mathrm{X}$ & $\mathrm{X}$ & $\mathrm{X}$ & $\mathrm{X}$ & $\mathrm{X}$ & $\mathrm{X}$ \\
\hline
\end{tabular}


TABLE A1.

continued

\begin{tabular}{|c|c|c|c|c|c|c|c|}
\hline \multirow[b]{2}{*}{ Taxon } & \multirow[b]{2}{*}{ Common name } & \multicolumn{2}{|c|}{ Clam beds } & \multicolumn{2}{|c|}{ Harvested } & \multicolumn{2}{|c|}{ Uncultivated } \\
\hline & & VA & NJ & VA & NJ & VA & NJ \\
\hline Dyspanopeus sayi & Equal-clawed mud crab & $\mathrm{X}$ & $\mathrm{X}$ & $\mathrm{X}$ & & $\mathrm{X}$ & $\mathrm{X}$ \\
\hline Eurypanopeus depressus & Flat mud crab & $\mathrm{X}$ & & $\mathrm{X}$ & $\mathrm{X}$ & $\mathrm{X}$ & \\
\hline Pagurus longicarpus & Long-wristed hermit crab & $\mathrm{X}$ & & $\mathrm{X}$ & & $\mathrm{X}$ & \\
\hline Pagurus pollicaris & Flat-clawed hermit crab & & & & & $\mathrm{X}$ & \\
\hline Libinia dubia & Six spined spider crab & $\mathrm{X}$ & & $\mathrm{X}$ & & $\mathrm{X}$ & \\
\hline Panopeus herbstii & Black fingered mud crab & $\mathrm{X}$ & & $\mathrm{X}$ & & & \\
\hline Tozeuma carolinense & Arrow shrimp & & & & & $\mathrm{X}$ & \\
\hline Neomysis americana & Mysid shrimp & & $\mathrm{X}$ & & $\mathrm{X}$ & & $\mathrm{X}$ \\
\hline Pinnixa sp. & Pea crab & & $\mathrm{X}$ & & & & \\
\hline Carinus Maenas & Green shore crab & & & & $\mathrm{X}$ & & $\mathrm{X}$ \\
\hline Cumacea & Hooded shrimp & & & & & $\mathrm{X}$ & \\
\hline Chthamalus fragilis & Fragile barnacle & & & $\mathrm{X}$ & & & \\
\hline Gammarus mucronatus & Amphipod & $\mathrm{X}$ & $\mathrm{X}$ & $\mathrm{X}$ & $\mathrm{X}$ & $\mathrm{X}$ & $\mathrm{X}$ \\
\hline Gammarus sp. & Amphipod & $\mathrm{X}$ & $\mathrm{X}$ & $\mathrm{X}$ & $\mathrm{X}$ & $\mathrm{X}$ & $\mathrm{X}$ \\
\hline Leptocheirus sp. & Amphipod & $\mathrm{X}$ & & & & & \\
\hline Cymadusa compta & Amphipod & $\mathrm{X}$ & $\mathrm{X}$ & $\mathrm{X}$ & & $\mathrm{X}$ & $\mathrm{X}$ \\
\hline Caprella penantis & Skeleton shrimp & & $\mathrm{X}$ & & & & \\
\hline Paracaprella tenuis & Skeleton shrimp & & $\mathrm{X}$ & & & & $\mathrm{X}$ \\
\hline Ampelisca sp. & Amphipod & $\mathrm{X}$ & $\mathrm{X}$ & $\mathrm{X}$ & $\mathrm{X}$ & $\mathrm{X}$ & $\mathrm{X}$ \\
\hline Corophium sp. & Amphipod & & $\mathrm{X}$ & & $\mathrm{X}$ & & \\
\hline Melita sp. & Amphipod & $\mathrm{X}$ & $\mathrm{X}$ & $\mathrm{X}$ & $\mathrm{X}$ & $\mathrm{X}$ & $\mathrm{X}$ \\
\hline Listrella clymenellae & Amphipod & & $\mathrm{X}$ & & $\mathrm{X}$ & & \\
\hline Listrella sp. & Amphipod & & & & & $\mathrm{X}$ & \\
\hline Erichsonella attenuate & Isopod & $\mathrm{X}$ & $\mathrm{X}$ & $\mathrm{X}$ & $\mathrm{X}$ & $\mathrm{X}$ & \\
\hline Edotia triloba & Isopod & & $\mathrm{X}$ & & & $\mathrm{X}$ & $\mathrm{X}$ \\
\hline Idotea bathica & Isopod & & & & & $\mathrm{X}$ & \\
\hline \multicolumn{8}{|l|}{ Merostomata } \\
\hline Limulus polyphemus & Horseshoe crab & & & & & $\mathrm{X}$ & \\
\hline \multicolumn{8}{|l|}{ Molluscs } \\
\hline Astyris lunata & Lunar dove snail & $\mathrm{X}$ & & $\mathrm{X}$ & & $\mathrm{X}$ & \\
\hline Crepidula fornicata & Atlantic slipper shell & $\mathrm{X}$ & & & & $\mathrm{X}$ & \\
\hline Doridella obscura & Limpet nudibranch & & & & & $\mathrm{X}$ & \\
\hline Placida dendritica & Nudibranch & & & & & $\mathrm{X}$ & \\
\hline Doris verrucosa & Sponge slug & & & $\mathrm{X}$ & & $\mathrm{X}$ & \\
\hline Tritia obsoleta & Eastern mud snail & $\mathrm{X}$ & $\mathrm{X}$ & $\mathrm{X}$ & $\mathrm{X}$ & $\mathrm{X}$ & \\
\hline Tritia trivittata & Threeline mud snail & & $\mathrm{X}$ & $\mathrm{X}$ & $\mathrm{X}$ & $\mathrm{X}$ & \\
\hline Melampus bidentatus & Eastern melampus & & & $\mathrm{X}$ & & & \\
\hline Turbonilla interrupta & Interrupted turbonilla & $\mathrm{X}$ & & & & & \\
\hline Bittium varium & Grass cerith & $\mathrm{X}$ & & $\mathrm{X}$ & & $\mathrm{X}$ & \\
\hline Pyrgocythara plicosa & Spindle-shaped turret snail & $\mathrm{X}$ & & $\mathrm{X}$ & & $\mathrm{X}$ & \\
\hline Triphora nigrocincta & Black-lined triphora & $\mathrm{X}$ & & $\mathrm{X}$ & & $\mathrm{X}$ & \\
\hline Phorontis vibex & Nassa mudsnail & & & & & $\mathrm{X}$ & \\
\hline Boonea bisuturalis & Two-sutured odostome & $\mathrm{X}$ & & $\mathrm{X}$ & & $\mathrm{X}$ & \\
\hline Crepidula plana & Flat slipper shell & & & & & $\mathrm{X}$ & \\
\hline Crepidula convexa & Convex slipper shell & & & $\mathrm{X}$ & & & \\
\hline Hydrobia sp. & Seaweed snail & $\mathrm{X}$ & & & & & \\
\hline Haminoea solitara & Solitary paper bubble & & & $\mathrm{X}$ & & & \\
\hline Anadara transversa & Transverse ark & $\mathrm{X}$ & & & & & \\
\hline Eupleura caudata & Thick-lipped oyster drill & & & & & $\mathrm{X}$ & \\
\hline Mulinia lateralis & Little surf clam & & & $\mathrm{X}$ & & $\mathrm{X}$ & \\
\hline Mercenaria mercenaria & Hard clam & $\mathrm{X}$ & $\mathrm{X}$ & $\mathrm{X}$ & $\mathrm{X}$ & $\mathrm{X}$ & \\
\hline Mya arenaria & Soft shell clam & & $\mathrm{X}$ & & & & \\
\hline Gemma gemma & Amethyst clam & & & $\mathrm{X}$ & & $\mathrm{X}$ & \\
\hline Lunarca ovalis & Blood ark & & & & & $\mathrm{X}$ & \\
\hline Tagelus divisus & Purplish razor clam & & & & & $\mathrm{X}$ & \\
\hline \multicolumn{8}{|l|}{ Polychaetes } \\
\hline Eteone sp. & Paddle worm & & $\mathrm{X}$ & & $\mathrm{X}$ & & $\mathrm{X}$ \\
\hline Phyllodoce sp. & Paddle worm & & $\mathrm{X}$ & & $\mathrm{X}$ & & $\mathrm{X}$ \\
\hline
\end{tabular}


Effects of Clam Aquaculture on Estuarine Biota

TABLE A1.

continued

\begin{tabular}{|c|c|c|c|c|c|c|c|}
\hline \multirow[b]{2}{*}{ Taxon } & \multirow[b]{2}{*}{ Common name } & \multicolumn{2}{|c|}{ Clam beds } & \multicolumn{2}{|c|}{ Harvested } & \multicolumn{2}{|c|}{ Uncultivated } \\
\hline & & $\overline{\mathrm{VA}}$ & $\overline{\mathrm{NJ}}$ & VA & $\overline{\mathrm{NJ}}$ & VA & $\overline{\mathrm{NJ}}$ \\
\hline Paranaitis sp. & Paddle worm & & $\mathrm{X}$ & & & & $\mathrm{X}$ \\
\hline Lepidonotus squamatus & Scale worm & $\mathrm{X}$ & & & & & \\
\hline Alitta succinea & Clam worm & $\mathrm{X}$ & $\mathrm{X}$ & $\mathrm{X}$ & & $\mathrm{X}$ & $\mathrm{X}$ \\
\hline Drilonereis sp. & Opal worm & & $\mathrm{X}$ & & & & $\mathrm{X}$ \\
\hline Lumbrineris sp. & Opal worm & & $\mathrm{X}$ & & $\mathrm{X}$ & $\mathrm{X}$ & $\mathrm{X}$ \\
\hline Polydora sp. & Blister worm & & & & & & \\
\hline Lepidonotus squamatus & Scale worm & $\mathrm{X}$ & & & & & \\
\hline Hydroides dianthus & Feather duster worm & $\mathrm{X}$ & & & & & \\
\hline Pectinaria gouldii & Ice cream cone worm & & $\mathrm{X}$ & & & & \\
\hline Spiochaetopterus oculatus & Cellophane tube worm & & & $\mathrm{X}$ & & $\mathrm{X}$ & \\
\hline Glycera sp. & Bloodworm & $\mathrm{X}$ & & $\mathrm{X}$ & & $\mathrm{X}$ & \\
\hline Clymenella torquata & Bamboo worm & $\mathrm{X}$ & & $\mathrm{X}$ & & & $\mathrm{X}$ \\
\hline Arenicola marina & Lugworm & $\mathrm{X}$ & & & & & \\
\hline \multicolumn{8}{|l|}{ Nemerteans } \\
\hline Cerebrattulas lacteus & Milky ribbon worm & $\mathrm{X}$ & & & & & $\mathrm{X}$ \\
\hline \multicolumn{8}{|l|}{ Echinoderms } \\
\hline Sclerodactyla briareus & Brown sea cucumber & & & & & $\mathrm{X}$ & \\
\hline Thyonella gemmate & Green/common sea cucumber & & & & & $\mathrm{X}$ & \\
\hline \multicolumn{8}{|l|}{ Algae } \\
\hline Agardhiella sp. & Red algae & $\mathrm{X}$ & $\mathrm{X}$ & $\mathrm{X}$ & $\mathrm{X}$ & $\mathrm{X}$ & $\mathrm{X}$ \\
\hline Ceramium sp. & Red algae & $\mathrm{X}$ & $\mathrm{X}$ & $\mathrm{X}$ & $\mathrm{X}$ & $\mathrm{X}$ & $\mathrm{X}$ \\
\hline Petalonia sp. & Red algae & $\mathrm{X}$ & & $\mathrm{X}$ & & & \\
\hline Gracilaria spp. & Red algae & $\mathrm{X}$ & $\mathrm{X}$ & $\mathrm{X}$ & $\mathrm{X}$ & $\mathrm{X}$ & $\mathrm{X}$ \\
\hline Polysiphonia sp. & Red algae & $\mathrm{X}$ & $\mathrm{X}$ & $\mathrm{X}$ & $\mathrm{X}$ & & $\mathrm{X}$ \\
\hline Ulva lactuca & Sea lettuce & $\mathrm{X}$ & $\mathrm{X}$ & $\mathrm{X}$ & $\mathrm{X}$ & $\mathrm{X}$ & $\mathrm{X}$ \\
\hline Leathesia marina & Green algae & & $\mathrm{X}$ & & & & \\
\hline Chaetomorpha sp. & Green algae & & & $\mathrm{X}$ & & & $\mathrm{X}$ \\
\hline Scytosiphon sp. & Brown algae & & $\mathrm{X}$ & & $\mathrm{X}$ & & \\
\hline \multicolumn{8}{|l|}{ Vascular plants } \\
\hline Zostera marina & Eelgrass & & & & $\mathrm{X}$ & $\mathrm{X}$ & $\mathrm{X}$ \\
\hline Ruppia maritime & Widgeon grass & & & & & $\mathrm{X}$ & \\
\hline
\end{tabular}

VA, Virginia; NJ, New Jersey. The "between rows" sites did not contain any unique taxa and are not shown for brevity. 